\title{
In-Situ Microbial Conversion of Sequestered Greenhouse Gases
}

\author{
DE-FG-02-03ER83606
}

\author{
Andrew R. Scott \\ Donna F. Balin \\ Altuda Energy Corporation \\ San Antonio, Texas \\ andrew@altuda.com

\section{Biswarup Mukhopadhyay} \\ Bioinformatics Institute, Virginia Tech \\ Blacksburg, Virginia \\ biswarup@vt.edu
}




\section{Table of Contents}

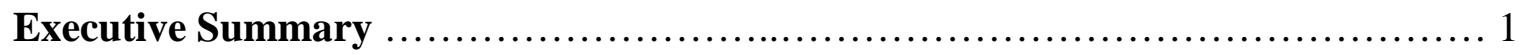

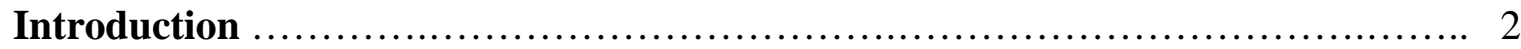

Preliminary Bioconversion Model .................................................. 5

Proposed Microbial Access to Reservoir............................................... 9

Defined Stakeholders ....................................................................... 7

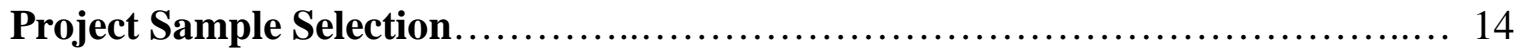

Collection of Whole Cores ..................................................... 21

Collection of Cutting Samples .................................................. 23

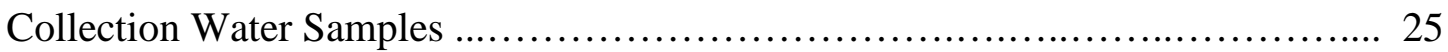

Coal Bioconverson and Stable Enrichment Development......................... 26

Economic Evaluation of In Situ Bioconversion..................................... 33

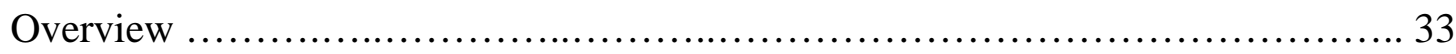

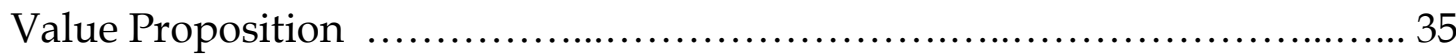

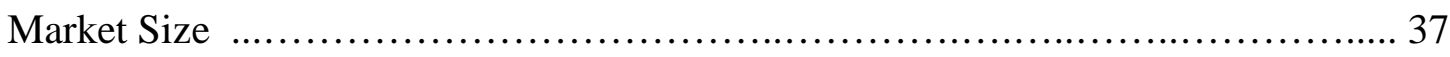

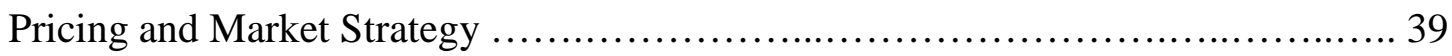

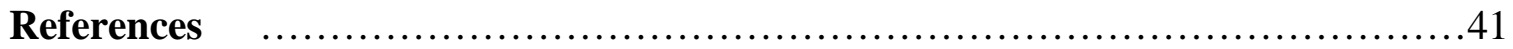

\section{FIGURES}

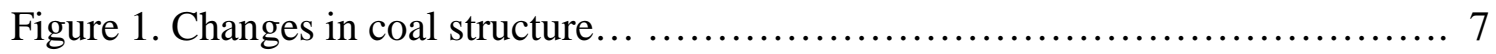

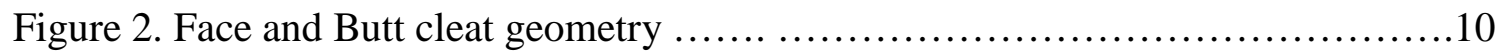

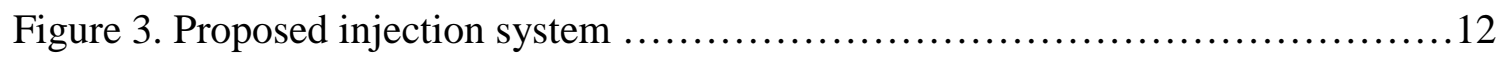

Figure 4. Proposed horizontal injection system ..................................12

Figure 5. Collection of whole core at drilling rig ................................. 22

Figure 6. Coal and microbial sampling equipments................................ 22

Figure 7. Shale shaker sample collection ....................................... 23

Figure 8. Simplified cuttings sample collection ................................. 24

Figure 9. Sample preservation system........................................... 25

Figure 10. Formation water sampling at well site .............................. 27

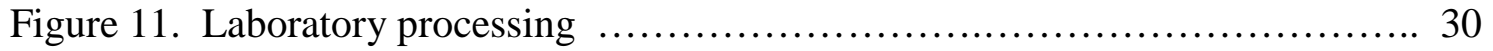

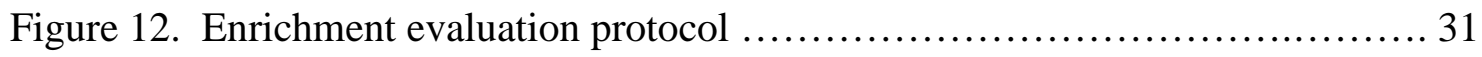

Figure 13. Natural gas supply chain ................................................ 34

Figure 14. Microbially Enhanced Coalbed Methane ............................... 34

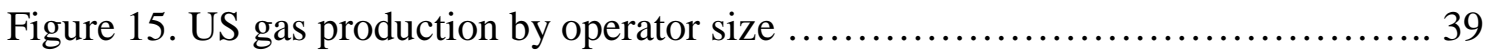




\section{Table of Contents (cont.)}

\section{TABLES}

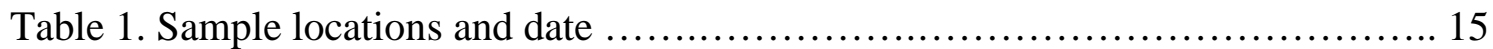

Table 2. Whole core sampling list ........................................... 17

Table 3. Cutting and maceral sampling list .................................... 18

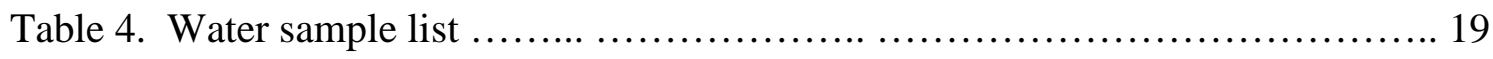




\section{EXECUTIVE SUMMARY}

The primary objective of this research was to collect, culture, and develop microbial enrichments that could be expanded into an innovative technology to bioconvert sequestered greenhouse gases (carbon dioxide) into methane in subsurface coal seams. Whole core, cutting, paraffin, and water samples were collected from coalbed methane wells and outcrops in five states with the active support of industry (coalbed methane operators) and academia. Multiple combinations of coal samples with formation water and nutrients were attempted over a 2.5 year time period. While nearly all cultures produced methane, we were unable to confirm sustained methane production from the enrichments. We believe that the methane generation may have been derived from readily metabolized organic matter in the coal samples and/or biosoluble organic material in the coal formation water. This raises the intriguing possibility that pretreatment of the coal in the subsurface to bioactivate the coal prior to the injection of microbes and nutrients might be possible.

The key factors affecting coal bioconversion identified in this research include (1) coal properties, (2) thermal maturation and coalification process, (3) microbial population dynamics, (4) hydrodynamics (5) reservoir conditions, and (6) the methodology of getting the nutrients into the coal seams. Additional concerns regarding the stabilization of subsurface microbial populations are also raised.

When this research was initiated, there was a large near-term need for natural gas production in the United States and the technology would potentially be economical under the prevailing gas prices. What was totally unanticipated was the exponential growth of the shale gas industry which went from trivial production and reserves in 2002 to 23.0 percent of the total gas production and 30.7 percent of total gas reserves in the United States in 2010. Regardless, an economic analysis of the project and recommended ways to move forward in injecting microbes in the subsurface are also covered in this report. We determined that it would be more cost effective to inject nutrients into coal seams to stimulate indigenous microbes in the coal seams, than to grow microbes in fermentation vats and transport them to the well site. If the coal bioconversion process can be developed, then the cost to generate methane could be less than $\$ 1$ per Mcf 


\section{INTRODUCTION}

This report summarizes the result of research conducted through the U.S. Department of Energy, Small Business Innovative Research Program (SBIR) though grant DE-FG-02-03ER83606 entitled "In-Situ Microbial Conversion of Sequestered Greenhouse Gases”. Energy and environmental concerns are often viewed from conflicting perspectives, but the in situ bioconversion of sequestered greenhouse gas technology described in this report may have the potential to resolve energy and environmental concerns simultaneously. The innovative concepts and research approaches presented in this Phase II Small Business Innovative Research report attempt to address both the increasing need for environmentally clean energy source (natural gas) and reduced greenhouse gas emissions (carbon dioxide).

Over the past decade, there has been a heightened interest in developing costeffective means for mitigating greenhouse gas emissions in response to increasing concerns regarding global climate change. Given the continued possibility of additional terrorist attacks on the United States and the possibility of additional wars in the Middle East, there is a strong incentive for the United States to develop new environmentally friendly, energy resources in order to reduce our dependence on foreign energy supplies. Despite efforts in expanding new clean-energy sources such as wind and solar power, fossil fuels will remain as the primary energy source for the world in the foreseeable future. Conservation of energy is an important means of reducing pollution, but the world population continues to grow at an almost exponential rate indicating that there will be a corresponding demand for more environmentally clean energy, particularly as the economies of less developed nations improve.

Although there is optimism regarding the possibility of using hydrogen fuels cells, but this technology probably will not take place without additional scientific breakthroughs. Furthermore, hydrogen cells currently require natural gas as a source for hydrogen, and unconventional gas resources, such as coalbed methane and shale gas, are becoming progressively more important. Coalbed methane production in the United States has increased from $10 \mathrm{Bcf}$ in 1985 to more than 1,866 Bcf in 2010 and now represents 8.2 percent of total dry gas production and 5.5 percent of proved dry gas reserves (Energy Information Association; 2012). As a comparison, shale gas production and reserves were 5.3 Tcf and 97.4 Tcf, respectively in 2010.

One of the advantages of sequestering $\mathrm{CO}_{2}$ in coal beds is the recovery of additional methane from the coal (Bryer and Guthrie, 1999a, b). The advantage of this process is that the carbon dioxide has a much stronger affinity for the coal and will preferentially displace methane from the coal while remaining sorbed to the coal surface. According to Bryer and Guthrie (1999b), for each molecule of methane released during $\mathrm{CO}_{2}$ sequestration, two molecules of $\mathrm{CO}_{2}$ remain in the coal. Herzog (1998) states that the $\mathrm{CO}_{2}$ emission rate of the United States from fossil fuel combustion has grown an 
average of $0.65 \%$ per year since 1973 and stood at 5.88 billion tons of $\mathrm{CO}_{2}$ (103 Tcf of $\mathrm{CO}_{2}$ ) in 1997. Today, fossil fuel-fired power plants represent the largest source of air pollution in the United States. Every year, they collectively emit approximately 2.2 billion tons of carbon dioxide, 13 million tons of acid rain-producing sulfur dioxide, 7 million tons of acid rain- and smog-producing nitrogen oxides, and 43 tons of highly toxic mercury (Leahy, 2001). The United States is attempting to take the lead role in evaluating $\mathrm{CO}_{2}$ sequestration in geologic formations including underground aquifers, abandoned oil and gas reservoirs, and deep coal beds. The most cost-effective targets for the capture and sequestration of $\mathrm{CO}_{2}$ are from large, stationary, fossil fuel-fired power plants. These plants generate approximately one-third of the $\mathrm{CO}_{2}$ released annually in the production of energy for residential, commercial and industrial customers. Many of these coal-fired power plants are located adjacent to the coal resources, indicating that the $\mathrm{CO}_{2}$ and CO released as part of the flue gases could be sequestered in deeper, unmineable coal seams. DOE/EIA (1996) estimates that unmineable coal resources in the United States to depths of $6,000 \mathrm{ft}$ are 6.4 trillion tons, suggesting that significant amounts of $\mathrm{CO}_{2}$ and $\mathrm{CO}$ can be sequestered in deep coal seams near the point source. Bioconversion of only a small fraction of this carbon dioxide has significant economic benefits for the United States.

Research conducted in the early 1990s by the Bureau of Economic Geology, The University of Texas at Austin, demonstrated that biogenic gases in coal beds were associated with meteoric recharge rather than being generated in the peat swamp. Microbes transported basinward in ground water metabolized organic compounds on the coal, thereby converting them into methane (Scott and others, 1991, 1994a). Scott (1999) suggested that the naturally occurring bioconversion process could be enhanced through the addition of nutrients and/or microbes into coal beds. Scott (2001) further suggested that carbon dioxide sequestration followed by in situ bioconversion has the potential to convert sequestered $\mathrm{CO}_{2}$ into methane.

The Phase I and II research projects were designed to more fully understand and develop the in situ bioconversion of sequestered carbon dioxide and carbon monoxide in coal beds. An unexpected observation made during the Phase I research was that the in situ bioconversion technology may have a broader application in reducing greenhouse gas emissions than initially recognized. Naturally-occurring $\mathrm{CO}_{2}$ in coal beds may exceed 20 percent in some coal gases, and the $\mathrm{CO}_{2}$ content of the coal gases increases with time as the reservoir pressure declines. The $\mathrm{CO}_{2}$ is separated from the methane before the gas enters the pipeline system and then is often vented to the atmosphere. Tens of millions of tons of $\mathrm{CO}_{2}$ separated from coal gases potentially could be vented over the lifetime of some fields. Therefore, an in situ bioconversion technology applied to areas of unusually high $\mathrm{CO}_{2}$ content would not only generate tens of billions of cubic feet of environmentally friendly natural gas, but the technology would simultaneously reduce greenhouse gas emissions associated with coalbed methane production. 
Finally, bioconversion of sequestered $\mathrm{CO}_{2}$ and naturally-occurring $\mathrm{CO}_{2}$ through the addition of nutrients and/or microbial consortia (identified and modified in the laboratory) would generate additional methane representing a cleaner source of energy. Additionally, an abundant supply of low-cost natural gas would encourage the use of natural gas vehicles, the construction of more co-generation power plants, and possibly lower the cost of hydrogen fuel cells. The economic, social, and national security benefits to the United States will be substantial with this developed technology.

The in situ bioconversion of sequestered $\mathrm{CO}_{2}$ and naturally-occurring $\mathrm{CO}_{2}$ has farreaching economic, social, and national security benefits for the United States. From an environmental perspective, the bioconversion process results in several immediate benefits: (1) the removal of harmful greenhouse gases from the atmosphere through sequestration, (2) the release of more natural gas during the sequestration process as the $\mathrm{CO}_{2}$ dislodges methane from the coal surface (ECBM; enhanced coalbed methane), (3) the in situ bioconversion of sequestered $\mathrm{CO}_{2}$ and $\mathrm{CO}$ back into methane, and (4) the in situ bioconversion of naturally-occurring $\mathrm{CO}_{2}$ that will reduce greenhouse gas venting. The methane released and generated during the bioconversion of sequestered greenhouse gases can be used in co-generation processes to further reduce carbon dioxide emissions at coal-fired power plants. The social and economic impact of reducing potentially harmful emissions (in addition to $\mathrm{CO}_{2}$ ) and reducing air pollution from a health perspective would be significant.

According to Scott (1999), the in situ bioconversion of one-tenth of one percent (1/1000) of the coal resources in the United States would potentially result in the generation of $233 \mathrm{Tcf}$ of natural gas, or 41.4 billion barrels of oil equivalent (BOE). An updated review of the biogenic gas generation and economics are provided in this report. The in situ bioconversion of only a small part of our coal resources would provide nearly a 10-year supply of natural gas based on current consumption rates, representing a 1.16 trillion dollar industry at current gas prices ( $\$ 5.00 \mathrm{Mcf}$ ). Bioconversion of only 10 percent of the estimated $\mathrm{CO}_{2}$ annual emissions would be an additional 10 Tcf or an additional 30 billion dollar benefit. Removal of $\mathrm{CO}_{2}$ from coal gases before the gas is allowed into the pipeline is expensive, and a bioconversion technology that converts the $\mathrm{CO}_{2}$ into methane can significantly reduce $\mathrm{CO}_{2}$ removal costs. Finally, the in situ bioconversion technology could potentially turn a greenhouse gas purchased at $\$ 0.30$ per Mcf into a valuable commodity worth $\$ 5.00$ or more per Mcf. The secondary industries and technologies that would undoubtedly spin off from the bioconversion industry would be significant. The benefits associated with the identification of new microorganisms and their potential uses in a number of scientific fields are difficult to quantify at this point in time, but it is expected that there could be a significant impact on the economy of the United States and worldwide. 
A stable supply of natural gas represents a significant contribution to the energy security and national security of the United States. The technology would provide the nation with a stable source of clean energy that could not be easily impacted by international events. The proposed technology would not only provide a stable source of clean energy, but also encourages the use of natural gas in fossil fuel power plants and automobiles, and promotes the development of hydrogen fuel cells. An internal source of new energy could stimulate the United States economy, thereby reducing unemployment and increasing the tax revenue collected by the Federal government, while simultaneously improving the environment though the removal of greenhouse gases and other pollutants.

\section{PRELIMINARY BIOCONVERSION MODEL}

One of the objectives of this project was the development of a preliminary bioconversion model that integrated all of the potential factors affecting the bioconversion process in order to determine whether or not the bioconversion process was possible. The initial phase of our research effort determined that the in situ bioconversion of sequestered greenhouse gases was feasible, and the process will probably occur in real time rather than geologic time under the proper set of circumstances. However, the results of project laboratory experiments documented that the bioconversion process is more complex than initially considered and that there is a potentially delicate balancing act between nutrient supply, microbial growth rates, and removal of waste products. For example, we believe that if the nutrient supply is too large, exponential microbial growth may occur, thereby filling face cleats and butt cleats and even available pore space, thereby reducing permeability. The reduction of permeability then inhibits (1) the migration of new nutrients to the microbes and (2) the removal of potentially toxic waste products from the cleat system. Buildup of waste products can immobilize and kill certain species of microbes thereby disrupting the delicate microbial community balance required for the bioconversion process.

We identified several possible factors that may affect the coal bioconversion process that include (1) coal properties, (2) thermal maturation and coalification process, (3) microbial population dynamics, (4) hydrogeology, (5) reservoir conditions, and (6) the methodology of getting the nutrients into the coal seams.

Coal properties include coal composition (e.g. maceral types) and structure, ash content and quality (i.e. mineralogy for trace elements), cleat spacing or fracture frequency of the coal, moisture content, coal rank or thermal maturity level (which affects the coal structure and organic compounds in the coal), and the sorption characteristics of the coal. Macerals within coal beds are the types of organic matter that are identified microscopically and are often related to precursor organic compounds 
found in living entities. Different macerals contain different organic molecules and varying amounts of $\mathrm{H}: \mathrm{C}$ and $\mathrm{O}: \mathrm{C}$ ratios. Individual macerals can be grouped into four basic kerogen (organic matter) types based on the relative amount of oxygen, carbon, and hydrogen. Macerals with higher hydrogen contents are believed to be more generally more biodegradable than those with higher oxygen contents, because of the presence of readily biodegradable hydrogen-rich organic compounds. Biosolubility may be partially due to the sorption of nutrients or waste products on to the microporous coal surface which changes with maceral type and thermal maturation.

Type III kerogen (terrestrial organic matter with relatively high oxygen levels) has a very high sorption isotherm (large Langmuir Volume), which means organic and inorganic compounds are more readily sorbed to the coal surface. Type I kerogen (lacustrine or lake derived organic matter) and Type II (typical marine organic matter) hydrogen-rich kerogens have lower isotherms than the Type III kerogen. Most coals consist of all three types of kerogen with most falling between the Type II and Type III groups. Even though Type I and II kerogens have lower isotherms, they also contain significantly more hydrogen that can be used biocovert the kerogen into methane. The organic matter with the lowest sorption capacity is also the kerogen with the highest oxygen content. Type IV kerogen or intertinite was formed by frequent fires that occurred during peat deposition and is essentially charcoal-like. The highly oxidized intertinite has very little biosoluble organic compounds that microbes can utilize as a food source, because such material was consumed during peat fires.

The process of coalification begins in the peat swamp and continues until the coal reaches the graphite stage. Early coalification processes include the microbial degradation of organic matter in the peat swamp under aerobic and anaerobic processes. As the peat is buried deeper the coal is compacted and later heated at greater burial depths. As the temperature continues to increase the peat like structure (Figure 1a) undergoes structural rearrangement as water and carbon dioxide are first released and the coal lattice is re-arranged into a more condensed ring-like structure (Figure 1b). The thermal re-arrangement of the biologically inert organic matter in the peat swamp created during microbial activity, is why the coals can become more biosoluble with increasing thermal maturity. Note that while coal bioconversion can occur at any level of thermal maturity, the more biosoluble coals are believed to be those which have undergone a moderate degree of thermal maturation to the high-volatile $b$ bituminous to low-volatile bituminous. At higher levels of thermal maturation the number of ring structure increases and the amount of hydrogen available for bioconversion decreases. Hydrogen-rich coals often have generated appreciable quantities of wet gases and n-alkanes that may be more readily bioconverted into secondary biogenic methane. Therefore, the highest rank coals such as semi-anthracite, anthracite, and graphic have most likely have little potential for coal bioconversion. 


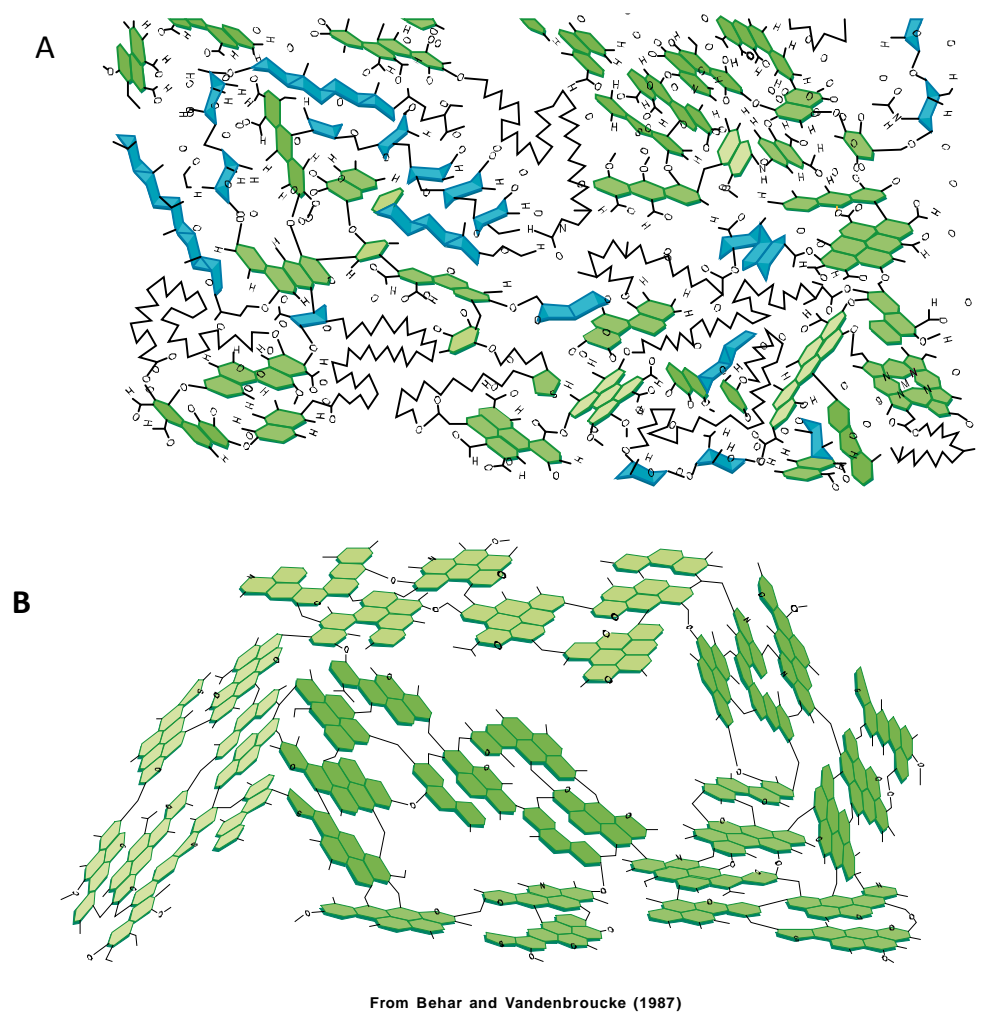

Figure 1. Changes in coal structure with thermal maturation. (a) peat structure contains large amounts of water and carbon dioxide and few ring-like structure. (b) during thermal maturation as the coal approaches the bituminous coal rank, the volatile components are driven off (water and carbon dioxide) and the coal structure is rearranged to become more condense as carbon ring structures become more prevalent. Wet gases, normal alkanes and other organic compounds generated during thermal maturation are the food supply for microbes in the subsurface.

Microbial degradation of organic compounds often requires the interaction of different microbial species acting in microbial consortia. Individual species in such a consortia feed off of the waste products of other species in a synergistic interplay. At least three functionally different trophic groups are required to convert organic matter into methane (Winfrey, 1984; McInerney and Beaty, 1988; Theil and others, 1988) (hydrolytic fermentative microbes, (2) syntrophic acetogenic microbes, and (3) methanogenic microbes. Microbial population dynamics include the types and quantities of anaerobic microbes responsible for coal bioconversion and the manner in which various species, within the trophic groups mentioned above, interact with each other. 
These are very complex mixed cultures that feed off of multiple substrates in generally non-steady state conditions; under some circumstances, stabilization of the consortia may result in steady state conditions. There may be multiple biogeochemical processes at work and generally the most biosoluble organic compounds are the first metabolized as part of the diauxic growth cycle where less biosoluble compounds are subsequently consumed. The dynamics of microbial interactions has rarely been studies in detail due to the complexity of the consortia. Additionally, very little research has been conducted into the effects of microbial death on consortia activity. A rapid increase in microbial growth followed by microbial death as nutrient supplies decline could result in some type of cryptic growth where microbes of the same or different strains start to metabolize the solubilized lysis products. Under this scenario, the coal bioconversion process could break down as the primary food sources become predominantly the waste products of earlier microbes. The complex interplay among various species in a consortia competing for food sources when coupled with access to nutients and the coal surface is probably the biggest limiting factor in coal bioconversion.

Coal seams are often the major aquifer systems in geological sequence because adjacent shales and sandstones that have undergone diagenesis tend to have much loer permeability. Therefore, coal hydrogeology and permeability heterogeneity affect the transport of microbes and nutrients through permeable coal seams and dictate where viable microbes are more likely to be located within a basin. The face cleats, and sometimes the butt cleats, are the primary permeability conduits in coal seams. The cleats may be readily visible at surface outcrops, but as overburden increases, the aperture of the cleats decreases resulting in a dramatic decrease in permeability. Most coalbed methane reservoirs worldwide are less than 3,500 feet $(1,067 \mathrm{~m})$ because permeability at depths greater than this is so low that sustained. economic production is not possible. The aperture sizes of these cleats in the subsurface probably range from 3 to $4+$ microns and are wide enough for microbes to access the coal (Scott, 1999). Meteoric recharge from the surface is probably responsible for moving microbes and nutrients into the subsurface through permeable coal beds. Meteoric flow or recharge is impacted by coal continuity, faulting, permeability and the precipitation of authigenic minerals into face and butt cleats which reduces permeability and inhibits recharge.

Reservoir conditions include temperature, pressure, and the types of coal gases that are sorbed to coal surfaces. Pressure will probably have a minimal effect on bioconversion, but microbes can be highly sensitive to temperature conditions. As temperature increases beyond approximately $140^{\circ} \mathrm{C}$ then microbial populations become thermophillic and more difficult to culture in the laboratory. Most shallow coal seams in basins worldwide are believed to be at temperatures conducive to bioconversion. The exact impact on pressure and temperature remains unknown in the bioconversion model, but pressure and temperature could affect the geometry of how organic molecules are sorbed to the coal surface and, therefore, the biosolubility of the organic molecules. 
Given the difficulties in culturing complex microbial consortia, the techniques to test the effect of temperature and pressure are beyond the scope of this research project.

Examples of real time bioconversion include methane generation in peat swamps and rice paddies and in bovines. Some coalbed methane operators have reported that microbes trapped in coal cutting samples that were placed in cans for laboratory analyses generated methane between the time the samples were collected at the well site and transported to the laboratory. The U.S. Geological survey recently supported these claims after some of their cutting samples started to generated methane after several months in the laboratory (Barker, 2005). Bacteriacides are now often placed in sample collection canisters to prevent microbial generation of methane from occurring. Recent research by the Alberta Research Council indicated that microbes under laboratory conditions would generate from 28 to $1,052 \mathrm{scf} /$ ton/day (standard cubic feet per ton of coal per day; Budwill, 2003). We believe that the reaction rates in the subsurface will be less than bioconversion rates reported by the Alberta Research Council. Therefore, we have based our financial forecasts and economic considerations in this Business Plan on bioconversion rates less than $0.5 \mathrm{scf} /$ ton/day, although we believe higher rates may be possible under optimum conditions.

\section{$\underline{\text { Proposed Microbial Access to Reservoir }}$}

Relatively little research has been performed on the composition of subsurface bacterial consortia, indicating that there are a significant number of bacterial species that have yet to be discovered. In some cases, a key nutrient or trace element may be missing, and addition of this limiting factor may significantly increase methane production. When bacteria are deprived of nutrients physiological changes occur, and if the state of starvation continues, all metabolic systems cease to function and the bacteria undergo metabolic arrest. However, when environmental conditions change, the bacteria may recover and establish a viable population again. Therefore, it is possible that some bacteria in organic-rich sediments have reached a state of metabolic arrest and the addition of nutrients is all that is required to activate the population under the present invention. Bacteria from sediments more than one million years old have been successfully revived, indicating that these bacteria can be utilized in the bioconversion process. Therefore, once the correct microbial mix and nutrients have been identified, it is critical to assure that a sufficient number of viable microbes are delivered into the subsurface in a minimum concentration level for bioconversion to occur.

The injection of microbes into coal seams can take advantage of the current methodology for stimulating coalbed methane production. Most coal beds are stimulated prior to production following standard industry practices of reservoir fraccing but may also include open hole cavity completions. Hydrofracture (frac)stimulation is the most common practice, but care must be used in selecting fluids that come in contact with the reservoir because the coal may react adversely with the stimulation fluids. During open-hole cavity completions, the reservoir is pressurized and then suddenly depressurized causing the friable coal to slough 
off into the wellbore and be carried to the surface, thereby creating a large cavity. There are several methods or combination of injection techniques that might be utilized to assure that when the bacteria and nutrients are injected into the fractures they access the largest part of the reservoir as possible, and therefore, assure maximum bioconversion rates. This assumes that the bioconversion rate is proportional to the surface area available for microbial activity - the greater the access to the coal reservoir (cleat system) the more likely that bioconversion will occur. Fracture orientation, present-day in situ stress direction, reservoir (coal and/or shale) geometry, and local structure must be taken into consideration when injecting bacteria and nutrients into the organic-rich reservoir. For example, there are two major networks (called cleats) in coal beds, termed the face cleat and butt cleat system. The face cleats are often more laterally continuous and permeable, whereas the butt cleats, which form abutting relationships with the face cleats are less continuous and permeable (Figure 2). During the stimulation of coalbed methane wells, the induced fractures intersect the primary face cleats that allow greater access to the reservoir. However, when the presentday in situ stress direction is perpendicular the face cleats, then stress pressure closes the face cleats thereby reducing permeability, but at the same time in situ pressures increase permeability of the butt cleats system. Under these conditions, induced fractures are perpendicular to the butt cleat direction, providing better access to the natural fracture system in the reservoir (Figure 3). The geometry of the injection and producing wells, and whether or not horizontal cells are used to access the reservoir, depend largely upon local geologic and hydrodynamic conditions.

A

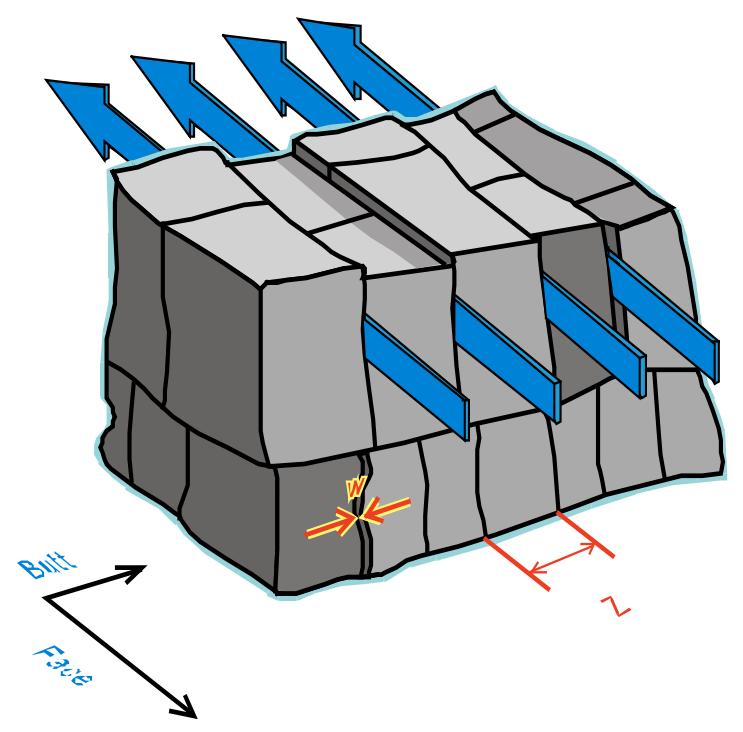

B

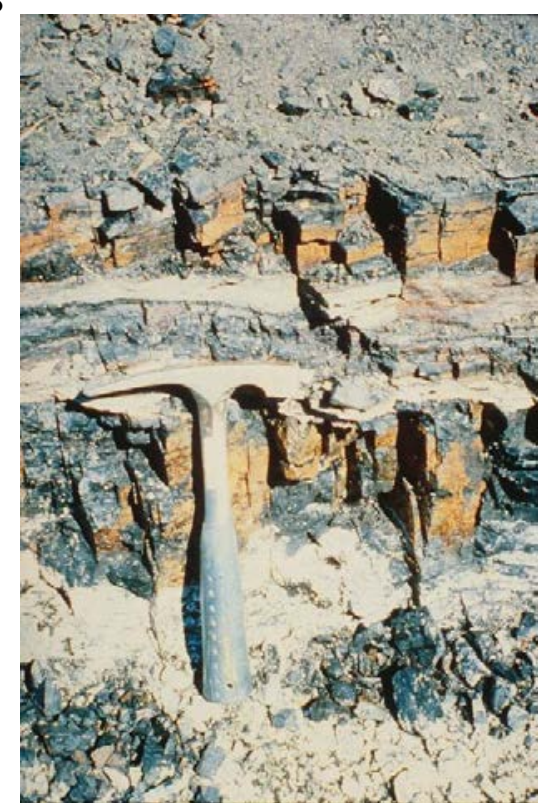

Figure 2. Face and Butt cleats in coal beds. (a) face cleats are the first formed and more continuous and often have the best permeabily (blue arrows). (b) face and butt cleats in coal outcrop. The butt cleats have yellowish tinge to them, whereas the more continuous face cleats are shown in the shadows 
During fraccing a sand or ceramic proppant is injected with various, highly diluted chemicals under high pressure that fractures (cracks) the reservoir. The sand proppant enters into the reservoir under high pressure and when the injection pressure is reduced, the newly created fracture collapses upon itself, but sand props remains in the fracture keeping it open. The sand also serves a highly permeable conduit that allows fluids and gases to more easily flow from the reservoir, or in this technology, into the reservoir. In other words, these same hydraulic fractures with the permeable sand proppant (Figure 3) can subsequently be used to inject bacteria and/or nutrients into the well bore. Bacteria and nutrients may be injected into the reservoir at the same time as fracture stimulation and/or after the hydraulic fractures are generated. Most in situ microbial applications are expected to occur after fracture stimulation and removal of completion fluids when subsurface anaerobic conditions are re-established. However, under simultaneous in situ microbial and fracture stimulation, the use of stimulation fluids under anoxic or suboxic conditions is preferred so that anaerobic conditions in the reservoir are maintained, or can be readily attained after stimulation. The injection of aerobic bacteria during simultaneous stimulation would result in the rapid consumption of oxygen and rapid return to anaerobic conditions. However, the preferred method for encouraging in situ bioconversion of organic matter is to inject bacteria and nutrients under pressure and anaerobic conditions after hydraulic fracture stimulation and subsequent flushing of the well. The mixture of bacterial consortia, nutrients, and water can be prepared at the well site. Of particular interest, is that methanogenic microbes can readily survive in oxygenated environments for extended periods of time in the absence of oxygen (B. Mukhopadhyay, personal comm.) suggesting that the proposed process for getting the methanogens into the coal reservoir would be more likely to succeed. However, the stability of other microbial species in the consortia might be compromised during the process. Carbon dioxide and carbon monoxide that are initially sequestered in coal beds to serve as food sources for the bacterial consortia and these compounds can be brought to the well site by a pipeline system or transported under pressure in trucks.

Once access to the reservoir has been established, multiple injections of bacteria and nutrients, that may include different species or groups of bacteria, and/or various mixtures of nutrients may be injected into the well bore over a period of days, weeks, months, or years to promote stabilization of the subsurface consortia and optimize the in situ bioconversion rate of organic matter. In the case of carbon dioxide and carbon monoxide sequestration, injection of these gases followed by bacteria and/or nutrients and subsequent conversion to methane is repeated until the subsurface coal can no longer support bacterial activity at acceptable levels. Successful access to the reservoir, in situ bioconversion efficiency, and determination of the quantity of methane and other compounds generated during the process can be evaluated from small diameter observation wells strategically placed near the main well (or wells) to collect samples over time.

Following the hydraulic fracture stimulation and injection of bacteria and nutrients into the subsurface reservoir, the injection well would then be shut in for a period of time to allow the bacterial consortia to stabilize, thereby encouraging the bioconversion of the organic matter into various compounds and methane. After a brief stabilization time, the water and gases produced through the in situ bioconversion of the organic matter can be produced through the injection well bore along with gases already present in the reservoir (Figures 3,4). 


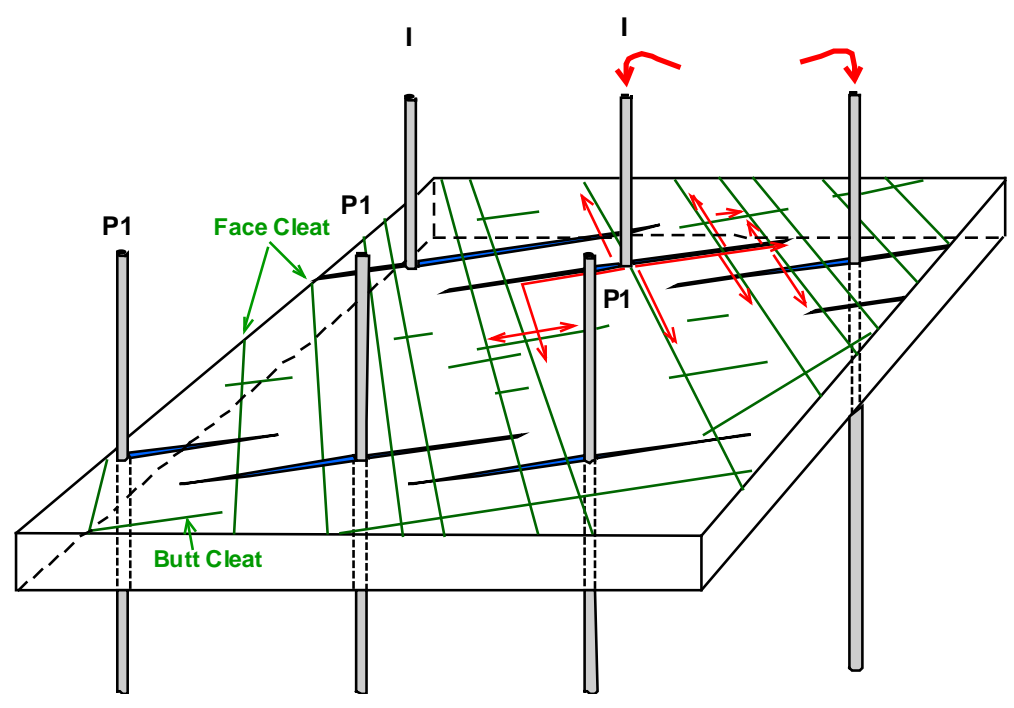

Figure 3. Proposed injection system for emplacing microbial consortia and/or nutrients into coal seams. Both injection wells (I) and production wells (P) are fracced to allow access to the face and butt cleat system in the coal seams. Microbes and/or nutrients are injected into the wells (red pathways) and into coal seam via the generated frac and naturally occurring fractures and cleats in the coal beds. The production wells can be located downdip to remove water, microbial waste products, and natural gas from the coal seams. The process can be continued by drilling a second set of production wells downdip of the first set, and then converting the old production wells into injections wells.

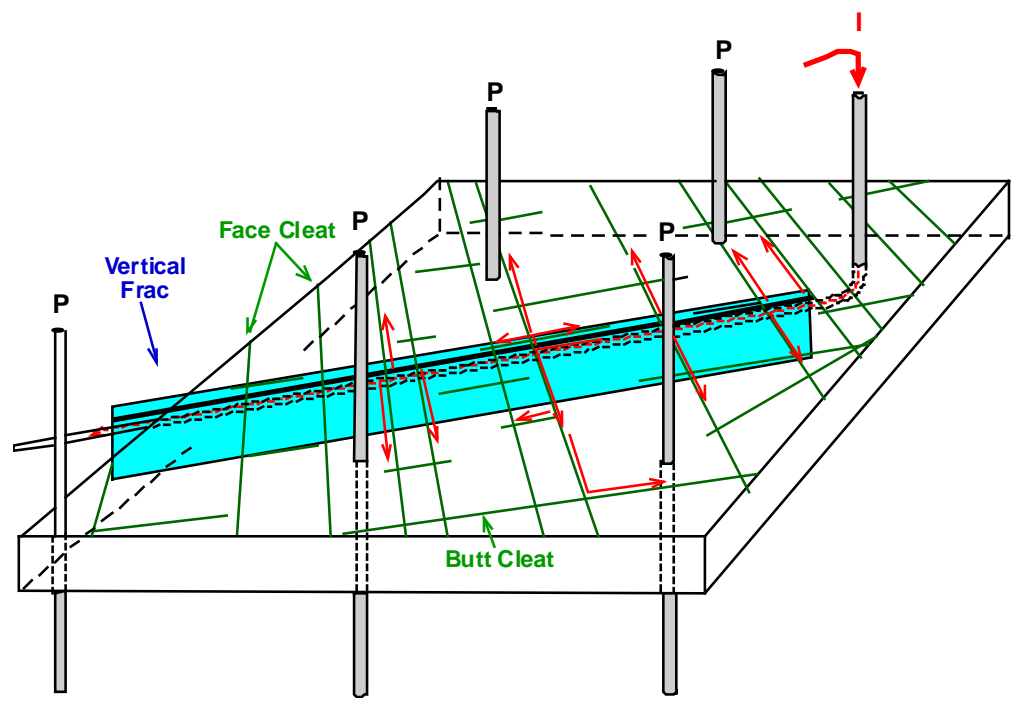

Figure 4. Proposed horizontal injection system for emplacing microbial consortia and/or nutrients into coal seams. The production wells (P) located on either side of the horizontal injection (I) well and both types of wells are fracced to better access the naturally occurring subsurface fractures and face and butt cleats in the reservoir, thereby maximizing the surface area available for microbial bioconversion. Microbes and/or nutrients are injected into the horizontal well and water, microbial waste products, and natural gas are produced from the coal seams. Alternatively, the production wells may be converted into injection wells, and the horizontal well can serve as the producing well. 
However, continued or frequent injection under pressure will most likely be more efficient at moving the bacterial consortia and nutrients to deeper parts of the reservoir in a more time efficient manner. One benefit of the methodology of using repeated injections is the removal of toxic waste products and introduction of fresh nutrients to the bacterial consortia. The injected fluids will tend to move through the larger and more permeable fracture system that are often the most continuous However, once the bacterial have entered deep into the reservoir via these natural fracture systems, the injected bacteria may then migrate under their own energy to smaller fractures and micro-fractures in the coal and organic- rich sediment, thereby accessing a volumetrically much larger part of the reservoir. The injected fluids, methane and other organic compounds formed from the in situ bioconversion of the organic matter are removed from the reservoir by a series of recovery or production wells (Figure xx) located downdip of the injection well. When bioconversion rates decline a second set of production wells can be drilled downdip of the first set of production wells which can then be converted into new injection wells. This process can be completed until coal properties or depth and permeability restrictions inhibit the bioconversion process.

A possibly more efficient means of accessing the coal reservoir for microbial injection is the use of horizontal injection wells. Horizontal drilling technology has expanded dramatically over the past five to ten years as shale gas exploration has taken off. The use of staged fracturing (or frac) in horizontal well laterals that may extend up to 10,000 feet (3,050 m) from the well bore would provide microbial consortia and nutrients maximum access to the coal seams (Figure 4). Production could occur from the horizontal well itself and/or productions wells located downdip from the horizontal well, (Figure 4). Coal geometry and present-day in situ stress direction will probably favor the application of horizontal injection well bioconversion. These horizontal wells would be drilled perpendicular to the more permeable cleat direction which is usually the face cleat direction. 


\section{PROJECT SAMPLE COLLECTION}

The coal bioconversion project received strong support from the oil and gas industry, coal mines, and academia for both phases of the project. At least nine coalbed methane operators provided access to active drilling sites and or well pads to collect core sample, cutting samples, water samples, and paraffin samples during Phase II of the project alone. Without the in-kind contributions provided by drilling and completing wells, and through access to these wells during or after drilling, the project would have cost prohibitive. In some cases, operators were willing to collect samples for the project using specialized sample containers sent to the company by Altuda Energy or the Bioinformatics Institute at Virginia Tech, thereby reducing travel costs for the project. In addition to CBM operators, Terra Tek (via Williams), The University of Wyoming, and the San Juan Coal Mine also provided samples for evaluation. The sample location and date, the type of samples collected, companies who provided samples, and samples of macerals isolated by Dr. Jack Crelling are provided in Tables 1 to 4. Finally, Dr. Mukhopadhyay developed a collaborative access to a laboratory in the Department of Chemistry at Fort Lewis College, Durango, Colorado. This allowed the project to utilize the laboratory equipment and store project equipment and samples at the facility, thereby significantly reducing project costs.

As the research evolved during the project, the search for microorganisms that could degrade coal was focused on both coal cutting and whole core samples that were quickly converted from oxic to anaerobic conditions using technques described herein. These samples were collected by Altuda Energy Corporation, the Bioinformatics Institute at Virginia Tech, or by coalbed methane operators who subsequently shipped the samples to Virginia Tech for evaluation and culturing. Our observations at the well site during cutting retrieval indicated that coal cutting samples are essentially contaminated by extraneous material and microorganisms. Therefore, the contaminated material combined with primarily external and possibly indigenous microorganisms have the potential to generate methane giving the appearance of methane generation from coal. In reality the methane generation most likely came from the bioconversion of external material or food sources. Additionally, the coal cutting samples are very small and have a large surface area suggesting that they cuttings could be easily oxidized or contaminated. Therefore, the likelihood of finding indigenous anaerobic microbes surviving within the cutting samples is probably very low. 
Table 1. Samples collected during project including location and Operator. B = Bulk sample; $\mathrm{Cc}=$ coal cuttings; Wc

= whole core; $\mathrm{W}=$ water samples; $\mathrm{P}=$ paraffin.

\begin{tabular}{|c|c|c|c|c|c|c|c|c|c|}
\hline $\begin{array}{l}\text { Lab } \\
\text { Type }\end{array}$ & $\begin{array}{c}\text { State } \\
\text { Number }\end{array}$ & Date & Well Name / Collection Site & TWN & RNG & Sec & 16th & Sample Type Sought & Operator / Contact \\
\hline & $\mathrm{CO} 1$ & 22-Sep-03 & Soda Springs & T32N & R12W & 1 & $\mathrm{~L}$ & Coal H2S samples & Southern Ute \\
\hline & $\mathrm{CO} 2$ & 22-Sep-03 & Methane Seep & T32N & $\mathrm{R} 12 \mathrm{~W}$ & 14 & $\mathrm{~F}$ & Coal H2S samples & Southern Ute \\
\hline & $\mathrm{CO} 3$ & 22-Sep-03 & Rock Shelter & T32N & R12W & 14 & C & Coal H2S samples & Southern Ute \\
\hline & $\mathrm{CO} 4$ & 22-Sep-03 & Coal Outcrop & T32N & $\mathrm{R} 12 \mathrm{~W}$ & 14 & G & Coal H2S samples & Southern Ute \\
\hline & $\cos$ & 22-Sep-03 & Coal Fire & T32N & R12W & 14 & $\mathrm{~K}$ & Coal H2S samples & Southern Ute \\
\hline & $\mathrm{co6}$ & 22-Sep-03 & Valencia Canyon Gap & T33N & R11W & 7 & $\mathrm{P}$ & Coal H2S samples & Southern Ute \\
\hline & $\mathrm{CO} 7$ & 22-Sep-03 & Methane Venting System & $n / a$ & $\mathrm{n} / \mathrm{a}$ & $\mathrm{n} / \mathrm{a}$ & $\mathrm{n} / \mathrm{a}$ & Coal H2S samples & Southern Ute \\
\hline & NM50 & $11-O c t-03$ & Riddle \#250S & & & & & Coal samples & Burlington \\
\hline & NM1 & 17-Oct-03 & Woodriver Com $300 \mathrm{~S}$ & T30N & R8W & 9 & G & Cutting samples & Burlington \\
\hline & NM2 & 18-Oct-03 & Cox Canyon Unit 8-C & T32N & R11W & 17 & $P$ & Cutting samples & Williams/Burlington \\
\hline & $\mathrm{CO} 8$ & 20-Oct-03 & Cowen Grace GU A-2 & T34N & R9W & 11 & K & Cutting samples & BP-Amoco \\
\hline & $\operatorname{cog}$ & 23-Oct-03 & Payne Evelyn GUA\#2 & T35N & R6W & 32 & 0 & Cutting samples & BP-Amoco \\
\hline & NM201 & 24-Oct-03 & Fruitland Outcrop samples & $\mathrm{n} / \mathrm{a}$ & $\mathrm{n} / \mathrm{a}$ & $\mathrm{n} / \mathrm{a}$ & $\mathrm{n} / \mathrm{a}$ & Bulk coal samples & \\
\hline & NM51 & 1-Nov-03 & Williams 224A & - & - & - & - & Coal cuttings & Williams Energy \\
\hline & UT1 & 8-Nov-03 & Soldier Creek 7-32H & $\mathrm{n} / \mathrm{a}$ & $\mathrm{n} / \mathrm{a}$ & $\mathrm{n} / \mathrm{a}$ & $\mathrm{n} / \mathrm{a}$ & Coal samples & Tera Tek \\
\hline B & CO301 & 16-Mar-04 & Southern Ute $32-10,6-4$ & T32N & R10W & 6 & & Cuttings & Southern Ute \\
\hline $\mathrm{Cc}$ & WY1 & 10-Jun-04 & Dry Willow State 34-36 & T76W & R44N & 36 & $\mathrm{o}$ & Cuttings & Anadarko \\
\hline $\mathrm{Cc}$ & KS? & 19-Sep-04 & State TFU 41C-1613 & T73W & $\mathrm{R} 51 \mathrm{~N}$ & 16 & & Cuttings? & Anadarko \\
\hline Wc & NM3 & 12-Apr-05 & Cox Canyon \#204 & T32N & R11W & 21 & K & Whole Core & Williams/Burlington \\
\hline Wc & WY2 & 27-Jul-05 & Barrett State-1 & Tight Hole & & & & Whole core feedstock & Bill Barrett Corporation \\
\hline Wc & WY3 & 27-Jul-05 & Barrett State-2 & Tight Hole & & & & Whole core feedstock & Bill Barrett Corporation \\
\hline \multirow[t]{3}{*}{ Wc } & WY404 & 10-Aug-05 & SRU 32-24-4877 & $\mathrm{T} 48 \mathrm{~N}$ & $\mathrm{R} 77 \mathrm{~W}$ & 24 & I & Whole Core in can & Williams \\
\hline & NM4 & 15-Sep-05 & Mary Lou \#5 & $\mathrm{T} 24 \mathrm{~N}$ & R10W & 32 & K & Paraffin and oil samples & Dugan Production \\
\hline & NM5 & 15-Sep-05 & Goldmetal \#1 and \#2 & $\mathrm{T} 24 \mathrm{~N}$ & R10W & 32 & K & Paraffin and oil samples & Dugan Production \\
\hline w & NM52 & 16-Sep-05 & WF State $16-2$ & - & - & - & - & Water samples & Western Gas \\
\hline W & NM53 & 16-Sep-05 & WF Federal $27 \# 3$ & - & - & - & - & Water samples & Western Gas \\
\hline w & $\mathrm{CO} 337$ & 16-Sep-05 & Southern Ute FC 33-10 \#7-2 & T33N & R10W & 7 & $\mathrm{~F}$ & Water samples & Southern Ute \\
\hline Wc & NM6 & 18-Sep-05 & Ropco 7 \#2 & T29N & R14W & 29 & $\mathrm{~N}$ & Whole Core & Western Gas \\
\hline $\mathrm{P} / \mathrm{W}$ & $\mathrm{CO} 10$ & 19-Sep-05 & Southern Ute FC $32-10$ 5-5 & T32N & R10W & 5 & - & Paraffin and water samples & Southern Ute (oily) \\
\hline W & co11 & 19-Sep-05 & Southern Ute FC 33-10 7-3 & T32N & R10W & 7 & - & Paraffin and water samples & Southern Ute \\
\hline W & $\mathrm{CO} 12$ & 19-Sep-05 & McCollough 34-10 \#28-2 & T34N & R10W & 28 & - & Paraffin and water samples & Southern Ute \\
\hline B & WY200 & 25-Oct-05 & Various Samples & - & - & - & - & Bulk Coal Samples & University of Wyoming \\
\hline W & NM7 & 20-Feb-06 & SJ Unit 32-8 \#245 & T328 & R8W & 11 & L & Water samples & ConocoPhillips \\
\hline W & NM8 & 20-Feb-06 & SJ Unit 32-8 \#230 & T32N & R8W & 28 & - & Water samples & ConocoPhillips \\
\hline W & NM9 & 20-Feb-06 & SJ Unit 32-8 \#231A & T32N & R8W & 28 & - & Water samples & ConocoPhillips \\
\hline \multirow[t]{6}{*}{ w } & $\mathrm{CO} 13$ & 20-Feb-06 & Zelletti \#331 & T32N & R9W & 28 & $\mathrm{E}$ & Water samples & ConocoPhillips \\
\hline & NM10 & 21-Feb-06 & Burlington 30-6 \#404S & T3ON & R7W & 23 & $\mathrm{O}$ & Paraffin and water samples & Burlington \\
\hline & NM11 & 21-Feb-06 & San Juan 30-6 \#481S & T3ON & R6W & 30 & - & Paraffin and water samples & Burlington \\
\hline & NM12 & 21-Feb-06 & San Juan 30-6 \#478S & T3ON & R6W & 29 & - & Paraffin & Burlington \\
\hline & NM55 & 21-Feb-06 & San Juan 30-6 \#404S & T30N & $\mathrm{R} 7 \mathrm{~W}$ & 23 & - & Paraffin and water & ConocoPhillips \\
\hline & NM56 & 21-Feb-06 & San Juan 30-6 \#478S & - & - & - & - & Paraffin & ConocoPhillips \\
\hline \multirow[t]{3}{*}{ w } & CO8A & 22-Feb-06 & Cowen Grace GU A-2 & T34N & R9W & 11 & K & Water Samples & BP-Amoco \\
\hline & $\operatorname{cogA}$ & 22-Feb-06 & Payne Evelyn GUA\#2 & T35N & R6W & 32 & $\mathrm{O}$ & No samples & BP-Amoco \\
\hline & $\mathrm{CO} 14$ & 22-Feb-06 & Payne Evelyn D1 & T35N & R6W & 31 & - & No samples & BP-Amoco \\
\hline w & $\mathrm{CO} 15$ & 22-Feb-06 & Payne Evelyn GU F1 & T35N & R6W & 32 & $\mathrm{~J}$ & Water samples & BP-Amoco \\
\hline w & $\mathrm{CO} 16$ & 22-Feb-06 & Payne Evelyn GU 1-8 & T35N & R6W & 32 & C & Water samples & BP-Amoco \\
\hline $\mathrm{Cc}$ & NM57 & 8-Mar-06 & Howell K $300 \mathrm{~S}$ & T3ON & R7W & 15 & $\mathrm{~F}$ & Coal cuttings & Burlington \\
\hline w & IL50 & 13-Mar-06 & Sage Energy \#1 & T5N & R13W & 32 & - & Coal whole core & Sage Energy \\
\hline $\mathrm{Cc}$ & WY50 & 17-Mar-06 & ABGU 4777-16-1 & - & - & - & - & Cuttings & Anadarko \\
\hline
\end{tabular}


Table 1 (cont). Samples collected during project including location and Operator. B = Bulk sample; $\mathrm{Cc}=$ coal cuttings; $\mathrm{Wc}=$ whole core; $\mathrm{W}=$ water samples; $\mathrm{P}=$ paraffin.

\begin{tabular}{|c|c|c|c|c|c|c|c|c|c|}
\hline $\begin{array}{c}\text { Lab } \\
\text { Type }\end{array}$ & $\begin{array}{c}\text { State } \\
\text { Number }\end{array}$ & Date & Well Name / Collection Site & TWN & RNG & Sec & 16th & Sample Type Sought & Operator I Contact \\
\hline Wc & WY51 & 21-Apr-06 & Table Mountain Federal 21-32 & $\mathrm{T} 45 \mathrm{~N}$ & R76W & 21 & 1 & Whole core & Anadarko \\
\hline Wc & NM13 & 17-Sep-06 & Williams Rosa Coal 347A & $\mathrm{T} 31 \mathrm{~N}$ & R4W & 11 & $\mathrm{~F}$ & Whole Core & Williams Energy \\
\hline \multirow[t]{3}{*}{ Wc } & WY505 & 17-Oct-06 & Hanna Draw Federal 2-2 & T3N & $\mathrm{R} 81 \mathrm{~W}$ & 2 & G & Whole core & Anadarko \\
\hline & NM14 & 18-Oct-06 & & $\mathrm{T} 28 \mathrm{~N}$ & R5W & 24 & L & Paraffin & ConocoPhillips \\
\hline & $\mathrm{CO} 20$ & 18-Oct-06 & McCollough \#27-3 & $\mathrm{T} 31 \mathrm{~N}$ & R10W & 27 & - & Water samples & Southern Ute \\
\hline \multirow[t]{7}{*}{ Wc/W } & $\mathrm{CO} 21$ & 18-Oct-06 & McCollough \#34-10 \#27-4 & $\mathrm{T} 34 \mathrm{~N}$ & R10W & 27 & $\mathrm{O}$ & Water samples & Southern Ute \\
\hline & NM15 & 19-Oct-06 & San Juan 28-4 \#202 & $\mathrm{T} 28 \mathrm{~N}$ & $\mathrm{R} 4 \mathrm{~W}$ & 18 & E & Paraffin sample & ConocoPhillips \\
\hline & NM16 & 19-Oct-06 & San Juan 28-4 \#201 & $\mathrm{T} 28 \mathrm{~N}$ & R4W & 18 & $A$ & Paraffin sample & ConocoPhillips \\
\hline & NM17 & 19-Oct-06 & San Juan 28-4 \#200 & $\mathrm{T} 28 \mathrm{~N}$ & $\mathrm{R} 4 \mathrm{~W}$ & 30 & 1 & Oil sample & ConocoPhillips \\
\hline & NM18 & 20-Oct-06 & Negro Canyon 101 and 101S & $\mathrm{T} 31 \mathrm{~N}$ & $\mathrm{R} 8 \mathrm{~W}$ & 12 & L & Water samples & ConocoPhillips \\
\hline & NM19 & 20-Oct-06 & Negro Canyon 103S & $\mathrm{T} 31 \mathrm{~N}$ & $\mathrm{R} 8 \mathrm{~W}$ & 1 & - & Water samples & ConocoPhillips \\
\hline & NM20 & 20-Oct-06 & Susco 16 State $1 \mathrm{E}$ & T32N & R8W & 16 & $\mathrm{C}$ & Water samples & ConocoPhillips \\
\hline \multirow[t]{2}{*}{ Wc } & WY405 & & Big George Unit 16-2 & $\mathrm{T} 47 \mathrm{~N}$ & $\mathrm{R} 77 \mathrm{~W}$ & 16 & c & Whole core & Anadarko \\
\hline & NM200 & - & San Juan Coal mine & - & - & - & - & Bulk Coal Samples & San Juan Mine, CO \\
\hline
\end{tabular}


Table 2 Whole core samples collected during project for laboratory work.

\begin{tabular}{|c|c|c|c|c|}
\hline Lab Number & Date collected & Well name & Depth (ft) & Notes \\
\hline \multicolumn{5}{|c|}{ Whole Core Samples } \\
\hline$\underline{\mathrm{CS}-062}$ & 19-Sep-05 & Ropco 7 \#2 & $422.1-422.2$ & 1st coal core \\
\hline$\underline{\mathrm{CS}-063}$ & 19-Sep-05 & Ropco 7 \#2 & $422.1-422.2$ & 2nd coal core \\
\hline CS-086 & 19-Dec-05 & Ropco 7 \#2 & $425-425.9$ & Green Seam 1 of 2 \\
\hline CS-087 & 19-Dec-05 & Ropco 7 \#2 & $425-425.9$ & GreenSeam 2 of 2 \\
\hline CS-089 & 10-Aug-05 & SRU 32-24-4877 & $1311-1311.2$ & pint can \# 419-1 pint can, coal core Big George \\
\hline CS-109 & 13-Mar-06 & Sage Energy \#1 & $795^{\prime}$ & Collected March 7, 2005 \\
\hline CS-110 & 13-Mar-06 & Sage Energy \#1 & $1081^{\prime}$ & Collected March 7, 2005 \\
\hline CS-111 & 13-Mar-06 & Sage Energy \#1 & 1098 & Can \#3 Rained durring collection collected 03/08 \\
\hline CS-108 & 8-Mar-06 & Howell K $300 \mathrm{~S}$ & $2677-2693^{\prime}$ & NW sect $15, \mathrm{~T} 30 \mathrm{~W}, \mathrm{R} 8 \mathrm{~N}$ \\
\hline CS-113 & 17-Mar-06 & Big George Unit 4777-16-1 & $1622-1622.3$ & Big George \\
\hline CS-114 & 17-Mar-06 & Big George Unit 4777-16-1 & $1622-1622.3$ & Big George \\
\hline CS-115 & 18-Mar-06 & ABGU 4777-16-1 & 1650 & Big George \\
\hline CS-116 & 18-Mar-06 & ABGU 4777-16-1 & 1683.5-1684 & Big George \\
\hline CS-117 & 18-Mar-06 & ABGU 4777-16-1 & $1692-92.5$ & Massive \\
\hline CS-118 & 21-Apr-06 & Table Mountain Federal 21-32 & $1667.54-1668$ & Upper Canyon Coal \\
\hline CS-119 & 21-Apr-06 & Table Mountain Federal 21-32 & 1557 & Lower Big George \\
\hline CS-120 & 21-Apr-06 & Table Mountain Federal 21-32 & 1465 & Lower Big George \\
\hline CS-121 & 18-Sep-06 & Williams Rosa Coal 347A & $3920^{\prime}$ & Can \#1 Top 3' coal seam, \\
\hline CS-122 & 18-Sep-06 & Williams Rosa Coal 347A & $3928.2-28.5 .5 \mathrm{ft}$ & Broken core pieces covered with drilling mud \\
\hline CS-123 & 18-Sep-06 & Williams Rosa Coal 347A & 3937.5 & Solid core 3" length - Good Sample \\
\hline CS-128 & 1-Oct-06 & Williams Rosa Coal 347A & $\sim 4600$ & \\
\hline CS-129 & 1-Oct-06 & Williams Rosa Coal 347A & $\sim 4700$ & \\
\hline CS-130 & 1-Oct-06 & Williams Rosa Coal 347A & $\sim 4800$ & \\
\hline CS-131 & 1-Oct-06 & Williams Rosa Coal 347A & $\sim 4900^{\prime}$ & \\
\hline CS-132 & 1-Oct-06 & Williams Rosa Coal 347A & $3929 '$ & TVD; 5,000 ft offset \\
\hline CS-133 & 10-Oct-06 & Williams Rosa Coal 347A & 5135 & \\
\hline CS-135 & 17-Oct-06 & Hanna Draw Federal 2-2 & 4373.8 & Transfer 1st collected 10-22-05 \\
\hline CS-136 & 17-Oct-06 & Hanna Draw Federal 2-2 & 4718.8 & 1st collected 10-22-05 \\
\hline CS-137 & 17-Oct-06 & Hanna Draw Federal 2-2 & 4104.7 & 1st collected 10-22-05 \\
\hline CS-138 & 22-Oct-05 & Hanna Draw Federal 2-2 & & 1st collected 10-22-05 \\
\hline CS-139 & 17-Oct-06 & Hanna Draw Federal 2-2 & 4373.8 & 1st collected 10-22-05 \\
\hline CS-140 & - & Big George Unit 16-2 & 4718.8 & Lower Tongue River \\
\hline CS-141 & 10-Jun-04 & Dry Willow State 34-36 & 2539 & Upper Tongue River \\
\hline CS-142 & 10-Jun-04 & Dry Willow State 34-36 & 2375 & Upper Tongue River \\
\hline CS-143 & - & Big George Unit 16-2 & 2395 & Upper Tongue River \\
\hline CS-144 & 21-Apr-06 & Table Mountain Federal 21-32 & 1433 & Big George \\
\hline CS-145 & 21-Apr-06 & Table Mountain Federal 21-32 & 1495 & Big George \\
\hline CS-181 & 19-Sep-05 & McCollough 34-10 \#28-2 & & Red Willlow Production \\
\hline CS-182 & 19-Sep-05 & Southern Ute FC 32-10 5-5 & & T-32 N R-10W NMPM API \# 14-20-151-34A \\
\hline CS-053 & - & University of Wyoming & & AC-1: 80.79-81.25 and Run 2 15.0' (100\%) \\
\hline CS-054 & - & University of Wyoming & & AC-1: 81.25-82.00 and Run 2 15.0' (100\%) \\
\hline CS-055 & - & University of Wyoming & & 82.87-83.50 and Run 2 15.0' (100\%) \\
\hline CS-056 & - & University of Wyoming & & AC-1: 83.50-84.00 and Run 2 15.0' (100\%) \\
\hline CS-057 & - & University of Wyoming & & OXD 85.00-85.75 and Run 3 15.0' (98\%) \\
\hline
\end{tabular}


Table 3 Coal cutting samples and isolated macerals collected for laboratory work.

\begin{tabular}{|c|c|c|c|c|}
\hline Lab Number & Date collected & Well name & Depth (ft) & Notes \\
\hline \multicolumn{5}{|c|}{ Coal Cutting Samples } \\
\hline CS-034 & 19-Sep-04 & State TFU 41C-1613 & 1080 & Wall Coal Seam \\
\hline CS-035 & 19-Sep-04 & State TFU 41C-1613 & 1079.0-1079.3 & Wall Coal Seam \\
\hline CS-036 & 22-Sep-04 & State TFU 41C-1613 & 1369 & U. Pawnee \\
\hline CS-037 & 23-Sep-05 & State TFU 41C-1613 & $1639^{\circ}$ & Dannar Coal \\
\hline CS-039 & 12-Apr-05 & Cox Canyon \#204 & 3305 & Blue Coal, API No. 30-045-32125 \\
\hline CS-040 & 12-Apr-05 & Cox Canyon \#204 & $\mathrm{n} / \mathrm{a}$ & Depth recorded on aluminum foil, API No. 30-045-32125 \\
\hline CS-041 & 12-Apr-05 & Cox Canyon \#204 & $\mathrm{n} / \mathrm{a}$ & Depth recorded on aluminum foil, API No. 30-045-32125 \\
\hline CS-042 & 12-Apr-05 & Cox Canyon \#204 & 3359.5 & Organic Carboneseous shale API No. 30-045-32125 \\
\hline CS-043 & 12-Apr-05 & Cox Canyon \#204 & 3390.05 & First coal seam cored. API No. 30-045-32125 \\
\hline CS-044 & 12-Apr-05 & Cox Canyon \#204 & 3343.3 & \\
\hline CS-045 & 12-Apr-05 & Cox Canyon \#204 & 3450.7 & Carboneseous shell, API No. 30-045-32125 \\
\hline CS-046 & 12-Apr-05 & Cox Canyon \#204 & 3464 & Main coal, API No. 30-045-32125 \\
\hline CS-047 & 12-Apr-05 & Cox Canyon \#204 & 3563 & Shipped Later, API No. 30-045-32125 \\
\hline CS-048 & 16-Mar-04 & Southern Ute 32-10 6-4 & & San Juan U6, X Cut S82 Bench - 1500+g \\
\hline CS-049 & 27-Jul-05 & Wyodak Canyon & $1432.5-1435.5^{\prime}$ & Powder River Basin - 850g \\
\hline CS-050 & 27-Jul-05 & Big George & 1179-1180' & Powder River Basin - 990g \\
\hline CS-051 & 27-Jul-05 & Big George & - & Coal cores in metal gas sampling containers \\
\hline CS-052 & 27-Jul-05 & Big George & - & Coal cores in metal gas sampling containers \\
\hline \multicolumn{5}{|c|}{ Macerals (generated in the laboratory of Dr. John Crelling at Southern Illinois University, Carbondale, IL) } \\
\hline CS-059 & 10-Mar-05 & Hiawatha - Resin Concentrate & & Yellow powder \\
\hline CS-060 & 10-Mar-05 & Alpha Torbanite & & Algal rich \\
\hline CS-061 & 10-Mar-05 & Armfield & & Sporinite rich \\
\hline CS-059B & & $\begin{array}{l}\text { Hiawatha - Resin Conc., } \\
\text { Hiawatha seam Utah SIU561 }\end{array}$ & & Yellow powder \\
\hline
\end{tabular}


Table 4. Water samples collected for laboratory work. Many well water samples were anaerobic with low redox potential.

\begin{tabular}{|c|c|c|c|c|}
\hline Lab Number & Date collected & Well name & Depth (ft) & Notes \\
\hline \multicolumn{5}{|c|}{ CBM well water } \\
\hline CS-064 & 16-Sep-05 & WF State $16 \# 2$ & & Gas well water \#1 500 ml Serum Bottle \\
\hline CS-065 & 16-Sep-05 & WF Federal 27\#3 & & Gas well water \#2 $500 \mathrm{ml}$ Serum Bottle \\
\hline CS-066 & 16-Sep-05 & Southern Ute FC 33-10 7-2 & & Gas well water \#4 1 liter bottle \\
\hline CS-067 & 19-Sep-05 & Southern Ute FC 33-10 7-3 & & Yellow Paraffin, from pipe in 1 liter bottle \\
\hline CS-068 & 19-Sep-05 & Southern Ute FC 32-10 5-5 & & S. Ute well head water (high $\mathrm{H} 2 \mathrm{O}$ prod), aerobic (\#5) \\
\hline CS-069 & 19-Sep-05 & Southern Ute FC 32-10 5-5 & & S. Ute well head water (high $\mathrm{H} 2 \mathrm{O}$ prod), anaerobic (\#6) \\
\hline CS-070 & 19-Sep-05 & Southern Ute FC 33-10 7-3 & & Separator water \#3, $500 \mathrm{ml}$ Serum Bottle, anaerobic \\
\hline CS-071 & 19-Sep-05 & Southern Ute FC 33-10 7-3 & & Separator water \#4, $500 \mathrm{ml}$ Serum Bottle, aerobic \\
\hline CS-073 & 19-Sep-05 & Southern Ute FC 33-10 7-3 & & Tank water \#1, 500 ml Serum Bottle, pre-filter \\
\hline CS-074 & 19-Sep-05 & Southern Ute FC 33-10 7-3 & & Tank water \#2, 500 ml Serum Bottle, post-filter \\
\hline CS-075 & 16-Sep-05 & Southern Ute FC 33-10 7-2 & & Gas well water \#3 500 ml Serum Bottle \\
\hline CS-090 & 20-Feb-06 & SJ Unit 32-8 \#245 & & $\begin{array}{l}\text { Conoco Phillips, } 1 \text { liter of well water in nalgene container - } \\
\text { aerobic } \mathrm{pH}=7.65 \text {, redox=-195 }\end{array}$ \\
\hline CS-091 & 20-Feb-06 & SJ Unit 32-8 \#245 & & $\begin{array}{l}\text { Conoco Phillips, } 400 \mathrm{ml} \text { of well water in serum bottle - anaerobic } \\
\mathrm{pH}=7.65 \text {, redox }=-195\end{array}$ \\
\hline CS-092A & 20-Feb-06 & SJ Unit 32-8 \#230 & & $\begin{array}{l}\text { Conoco Phillips, } 1 \text { liter of well water in nalgene container - } \\
\text { aerobic } \mathrm{pH}=7.45 \text {, redox=-175 }\end{array}$ \\
\hline CS-092B & 20-Feb-06 & SJ Unit 32-8 \#230 & & $\begin{array}{l}\text { Conoco Phillips, } 1 \text { liter of well water in nalgene container - } \\
\text { aerobic } \mathrm{pH}=7.45 \text {, redox=-175 }\end{array}$ \\
\hline CS-093 & 20-Feb-06 & SJ Unit $32-8 \# 230$ & & $\begin{array}{l}\text { Conoco Phillips, } 400 \mathrm{ml} \text { of well water in serum bottle - anaerobic } \\
\mathrm{pH}=7.45 \text {, redox }=-175\end{array}$ \\
\hline CS-094A & 20-Feb-06 & SJ Unit 32-8 \#231A & & $\begin{array}{l}\text { Conoco Phillips, } 1 \text { liter of well water in nalgene container - } \\
\text { aerobic } \mathrm{pH}=7.30 \text {, redox }=-160\end{array}$ \\
\hline CS-094B & 20-Feb-06 & SJ Unit 32-8 \#231A & & $\begin{array}{l}\text { Conoco Phillips, } 500 \mathrm{ml} \text { of well water in nalgene container - } \\
\text { aerobic } \mathrm{pH}=7.30 \text {, redox }=-160\end{array}$ \\
\hline CS-095 & 20-Feb-06 & SJ Unit 32-8 \#231A & & $\begin{array}{l}\text { Conoco Phillips, } 400 \mathrm{ml} \text { of well water in serum bottle - anaerobic } \\
\mathrm{pH}=7.30 \text {, redox }=-160\end{array}$ \\
\hline CS-096 & 20-Feb-06 & gas well \# Zeletti 34-9\#331 & & $\begin{array}{l}\text { Conoco Phillips, } 1 \text { liter of well water in nalgene container - } \\
\text { aerobic } \mathrm{pH}=7.27 \text {, redox=-137 }\end{array}$ \\
\hline CS-097 & 20-Feb-06 & gas well \# Zeletti 34-9\#331 & & $\begin{array}{l}\text { Conoco Phillips, } 400 \mathrm{ml} \text { of well water in serum bottle - anaerobic } \\
\mathrm{pH}=7.27 \text {, redox }=-137\end{array}$ \\
\hline CS-103 & 22-Feb-06 & Grace Cowen GU-A-2 & & $\begin{array}{l}\mathrm{BP}, 1 \text { liter of well water in nalgene container - aerobic } \mathrm{pH}=7.9 \text {, } \\
\text { redox=-52 (fine spray from spigot) }\end{array}$ \\
\hline CS-104 & 22-Feb-06 & Grace Cowen GU-A-2 & & $\begin{array}{l}\mathrm{BP}, 400 \mathrm{ml} \text { of well water in serum bottle - anaerobic } \mathrm{pH}=7.9 \text {, } \\
\text { redox=-52 }\end{array}$ \\
\hline CS-105 & 22-Feb-06 & Evelyn Payne Unit F-1 & & $\begin{array}{l}\mathrm{BP}, 1 \text { liter of well water in nalgene container - aerobic } \mathrm{pH}=7.37 \text {, } \\
\text { redox=-109 }\end{array}$ \\
\hline CS-106 & 22-Feb-06 & Evelyn Payne Unit F-1 & & $\begin{array}{l}\mathrm{BP}, 400 \mathrm{ml} \text { of well water in serum bottle - anaerobic } \mathrm{pH}=7.37 \text {, } \\
\text { redox=-109 }\end{array}$ \\
\hline CS-107 & 22-Feb-06 & Payne GU1-8 & & $10 \mathrm{ml}$ in $500 \mathrm{ml}$ serum bottle \\
\hline
\end{tabular}


For these reason, our sample collection shifted from capturing cutting samples to whole cores. Whole core samples are normally 3.5 inch $(9 \mathrm{~cm})$ in diameter suggesting that even though the surface of the core could be contaminated, there could be microenvironments or niches within the center of the whole cores that would remain anaerobic and contain viable microbes. However, even though the whole core appeared to have the best probability of finding viable microbes, we continued our research on the4 cutting samples as well. There is always a possibility that a microbial consortia with the cutting samples could have the right combination of attributes to contribute to coal bioconversion. Regardless of coal sample type, our ultimate goal was to generate primary coal biodegradation using appropriate cultures under the coal reservoir conditions, particularly temperature. This strategy provided the best chance of cultivating the coal-bed microorganisms that were expected to be fastidious.

Another source of microorganisms that could potentially be used in the cultures and enrichments was formation water from the coal beds. The advantage is that by collecting a significant amount of water and keeping it anaerobic, any naturally occurring microbes could be concentrated and used in the enrichments. This approach assumes that the microbes existing in the formation water occur in the same proportions as the microbes with the consortia within the coal seams; this may or may not be the case.

Formation water from coal face and butt cleats must be removed by pumping in order for the reservoir pressure to decline and natural gas to be desorbed from the coals and migrating to the well bore for production. The dewatering phase can last from several months to several years or more depending on the proximity to outcrop and the permeability. Eventually, water production declines and eventually ceases when the well moves into the gas production stage. Therefore, timing of collecting samples and the location of the water samples is critical for selecting wells for microbial samples.

One of the goals of the research effort was to collect water samples from various locations within the San Juan Basin, Colorado and New Mexico that would represent water derived near the outcrop as well as formation water from deep in the basin where the most prolific CBM wells are located. The high productivity fairway in the San Juan Basin is defined by CBM wells that originally produce more than 2,000 Mcf/d. Many of the original wells in the high productivity fairway had been producing for more than a decade and were already in the gas production stage with little to no water production. However, we were fortunate to find some more recent wells that were located in the high productivity fairway and still had sufficient water production rates to collect water samples for microbial consortia. We were also fortunate that these wells had been on line for a long enough periods of time so that any chemicals associated with the well completion had been removed from the system and that the microbial consortia had once again reached equilibrium. 


\section{Collection of Coal Whole Cores}

In order to assure that the coal and water samples were collected properly and converted to anaerobic conditions as quickly as possible, the microbiology team from the Virginia Tech (VT), especially the VT Principal Investigator (PI; Dr. Biswarup Mukhopadhyay) and/or his assistant (Eric F. Johnson) were be present on the wells site to collect core samples as they came out of the core barrel. Whole cores were retrieved via a wireline recovery process that was designed to minimize the time required to get the core barrel containing the core to surface. Once the whole core was removed from the core barrel coal samples were selected and then taken to anaerobic conditions as quickly as possible to minimize the exposure of coal associated oxygen sensitive microorganisms to air. These oxygen sensitive (strictly anaerobic) microorganisms were likely to play critical roles in the envisaged generation of methane or other gaseous hydrocarbons from coal.

Figures 5 and 6 show the pictures taken during our work at the Cox Canyon \#204 well (Table 1). This was selected because it was on the southern margin of regional overpressure suggesting that there was a possibility of obtaining viable microbes and because it was the vertical part of a horizontal well that could have served as an injection well for the microbes at a later date. A sample processing station was established at the drilling site (Figure 6) where the battery of a car was used as the power source for the equipment. Figures 5c-f show pictures of a core in the core shack soon after it was removed from the core barrel; a small section of a core is shown in Figure 1g. The coal core samples that were provided for our research came from the sections shown in Figure 5d-f. The coal samples were placed under anaerobic conditions immediately after collection using the following methodology developed during this research. The coal samples were placed in a specialized container (* in Figure 6 ). The container was tightly closed and the contents were made anaerobic by 3 cycles of evacuation (by use of a vacuum pump) and pressurization with $\mathrm{N}_{2}+\mathrm{CO}_{2}$ atmosphere (80:20, vol/vol; 5 psi) (Balch and Wolfe 1976; Mukhopadhyay et al. 1999). The vacuum pump (**in Figure 6) was operated with power from a car battery (***in Figure 6$)$ and the gas mixture was supplied from a gas tank $\left({ }^{* * * *}\right.$ in Figure 6$)$. 

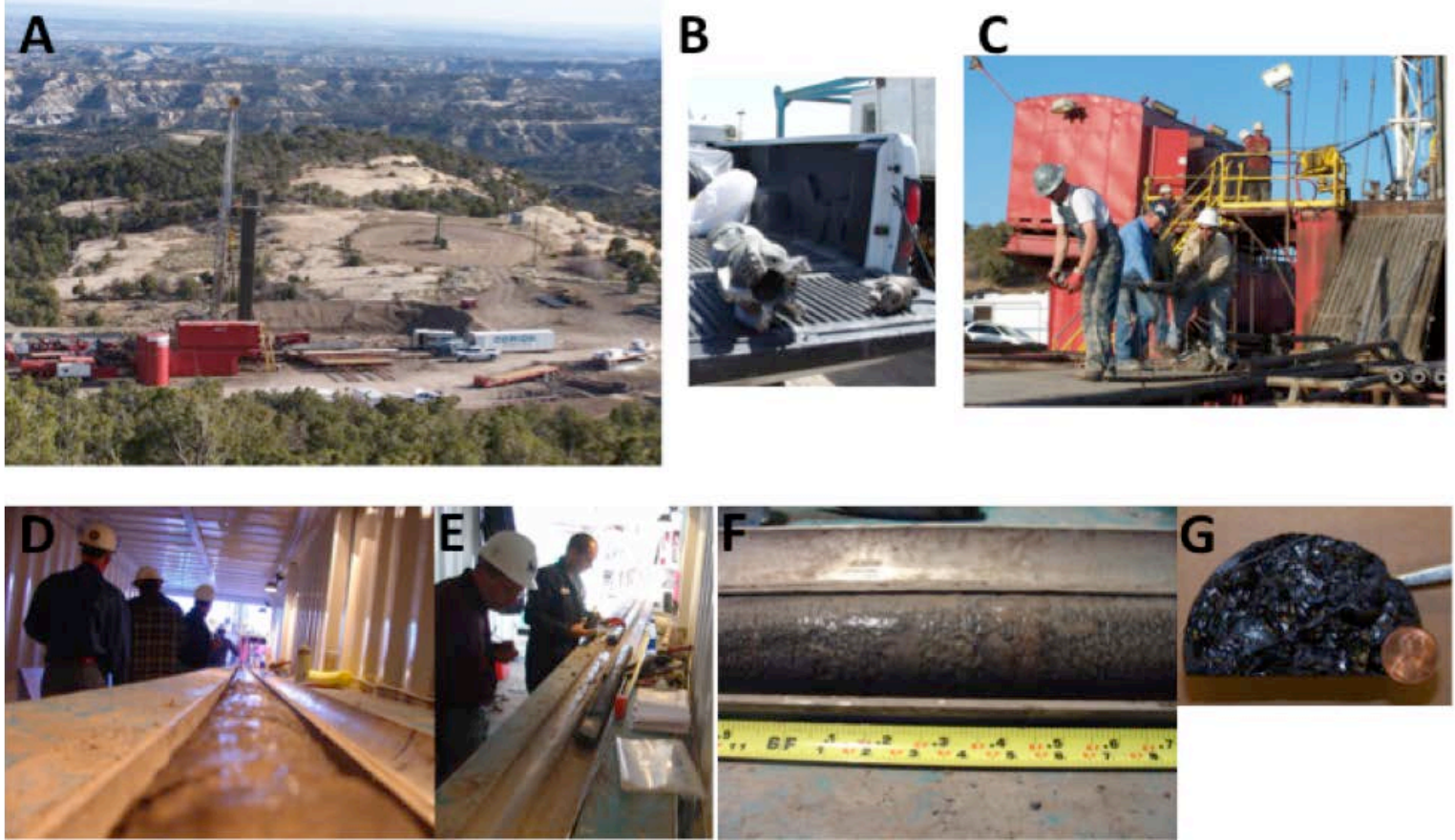

Figure 5. Collection of whole core samples from the Cox Canyon \#204 well drilling site in New Mexico.

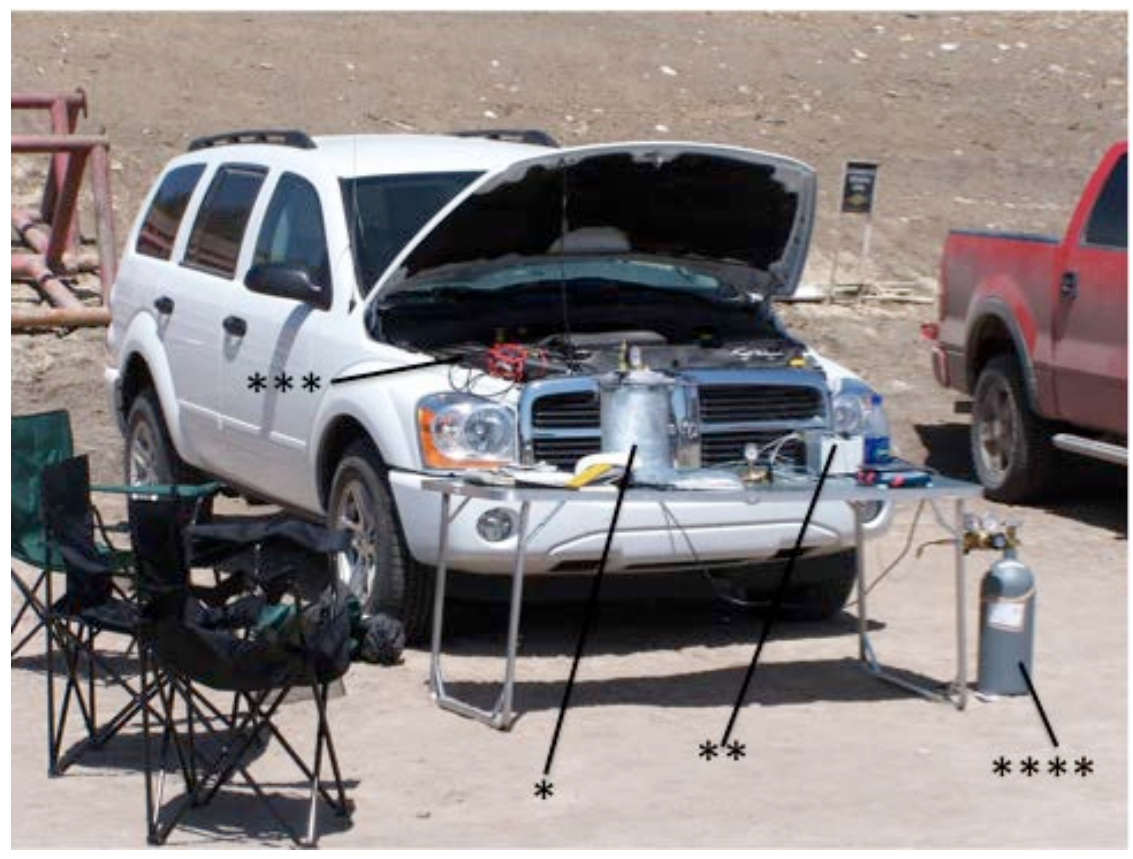

Figure 6. Core and microbial sample processing at drill site. 


\section{Collection of Cutting Samples}

Coal cutting samples were collected from the shale shaker using a large screen that allowed the drilling mud to pass through and the cutting samples to be retained in the sieve (Figure 7). As described above for the whole core samples, the coal cutting samples were also placed under anaerobic conditions right after collection. In our Phase II application we had described the procedure for such work, and we present the same in brief here. The drilling mud contained a mixture of highly aerobic water and chemicals used during the drilling program to minimize formation damage and to minimize the risk of blowout. Therefore, the microorganisms were exposed to near saturation level of oxygen and various chemical. The assumption was made that the organisms of interest had indeed survived this short time exposure to oxygen, but would not remain viable indefinite periods of time under these conditions. Therefore, once collected the cutting samples were placed into anaerobic conditions immediately after collected. The Virginia Tech team developed two systems for such purpose. Figure 8 shows a relatively simple system, which was given to the drilling rig operators to collect cutting samples in a metal paint can. The can was sealed with oxygen scavengers to remove oxygen from the sealed can. The can and anaerobic coal sample was subsequently shipped to Virginia Tech for evaluation . A more elaborate system that is described in Figure 6 was used by the Virginia Tech group during their visits. In some cases the collection container shown in Figure 6 (marked with *) was replaced with a pipe as shown in Figure 9.

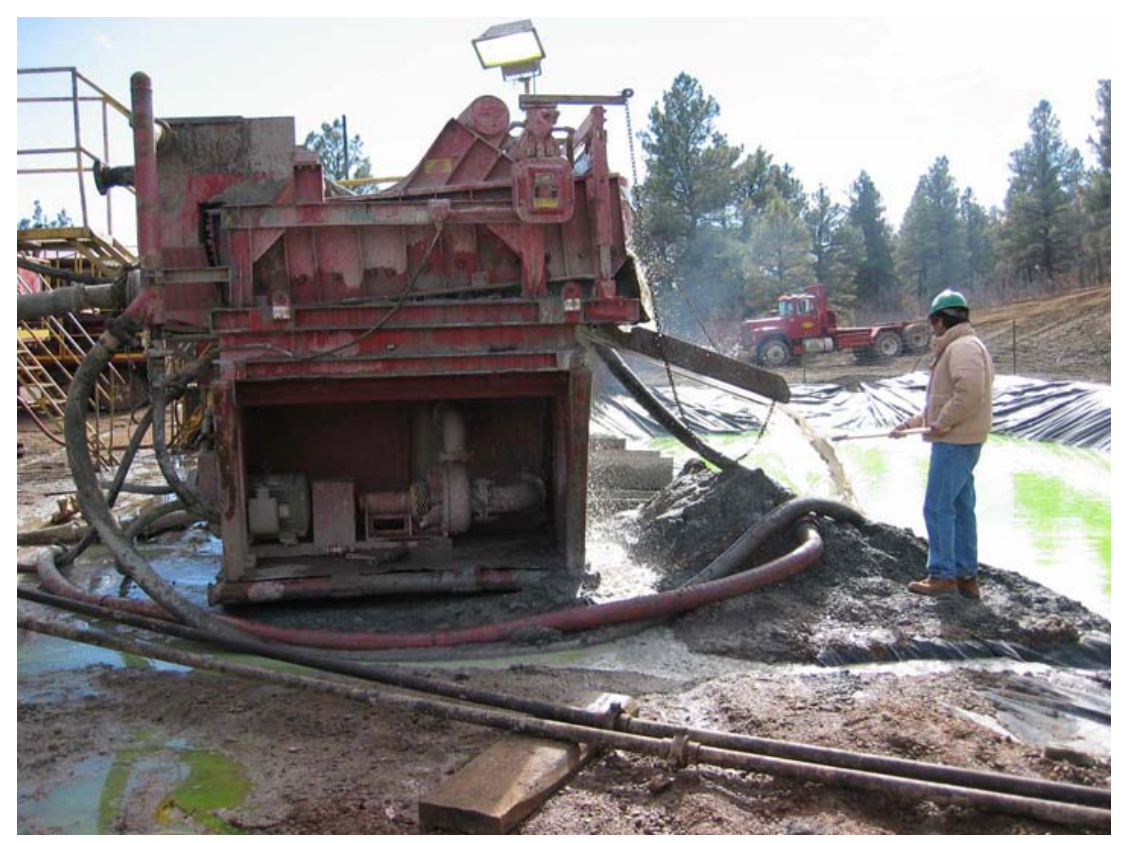

Figure 7. Collection of cutting samples from the shale shaker. 


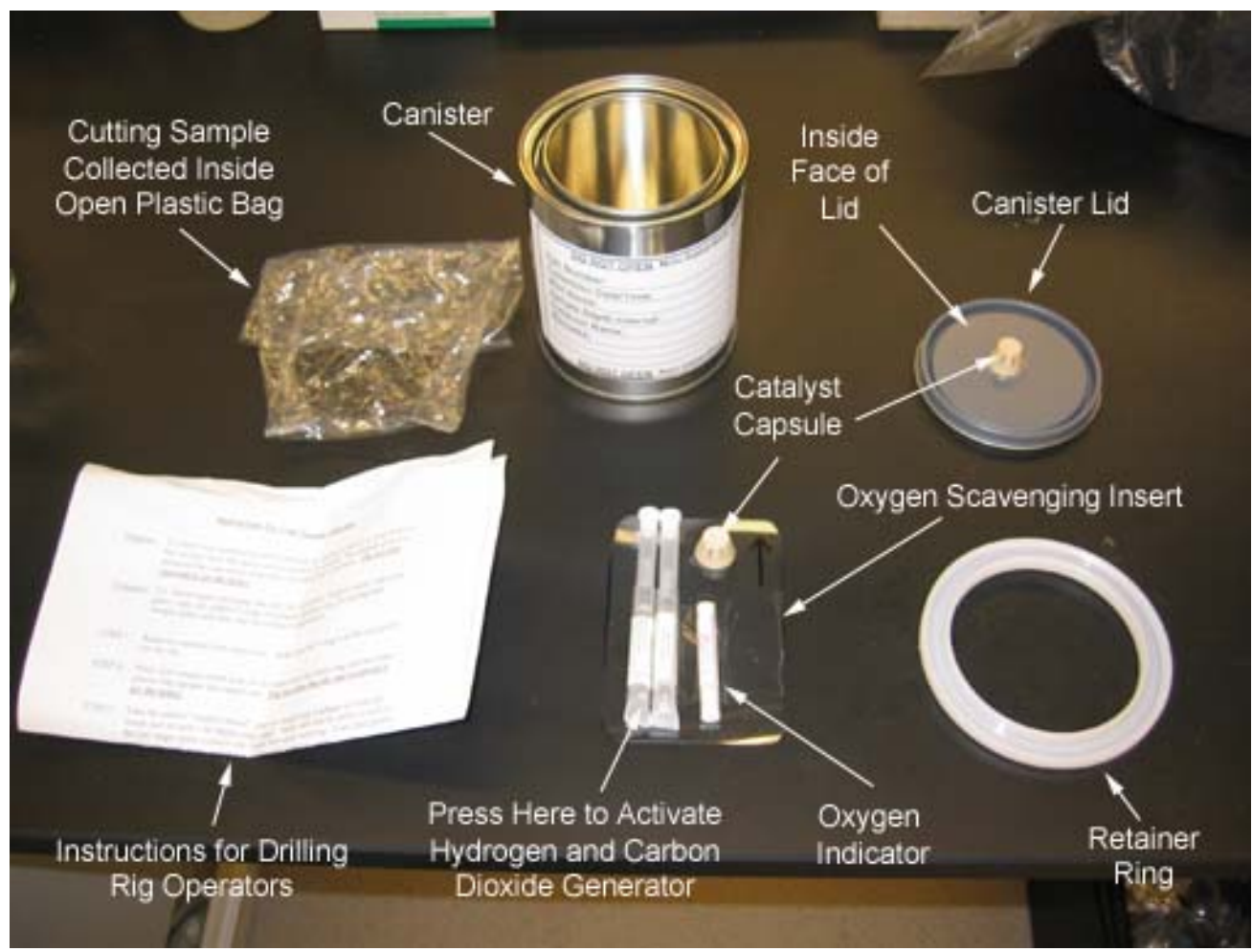

Figure 8. A can for the preservation and transportation of coal-bed well cutting samples. An open mouth plastic bag was filled with cutting samples. This filled bag and an oxygen-scavenging insert were placed in a can. The insert contained two plastic $\mathrm{H}_{2}-\mathrm{CO}_{2}$ generation tubes. Each tube carried a pellet and a sealed thin wall glass vial that contained an acid solution. The glass vial was crushed by putting the tube between fingers and by applying some pressure. This step brought the acid in contact with the pellet and helped to generate $\mathrm{H}_{2}$ and $\mathrm{CO}_{2}$. Immediately after crushing the glass vials inside gas generation tubes, the insert was placed inside the can by the side of the plastic bag and the lid was closed and sealed with a retainer ring. A reaction between $\mathrm{H}_{2}$ and oxygen on the catalyst made the interior of the can anaerobic 


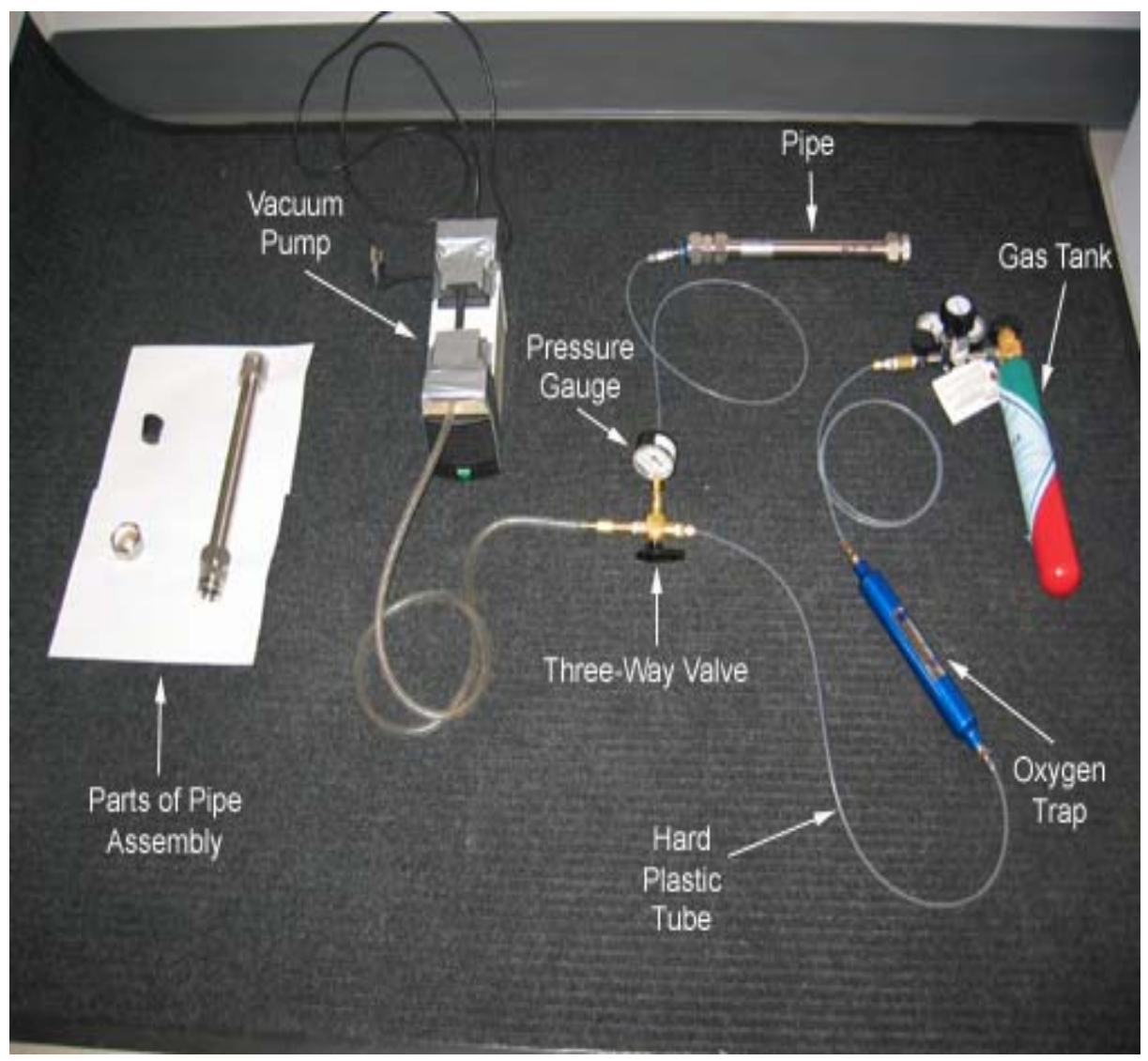

Figure 9. A system for preservation and transportation of coal-bed well cutting samples under rigorous anaerobic condition. The cutting samples were placed inside a 1" stainless steel pipe. One end of the pipe was sealed with a blind and the other with a rubber stopper and a screw cap. By use of a needle inserted through the rubber stopper and a tube attached to the needle, the interior of the sealed tube was connected to a vacuum pump and a nitrogen gas delivery system. With this syste the oxygen containing headspace gas inside the pipe was replaced with nitrogen. Then the pipe with anaerobic sample was shipped to the Virginia Tech.

\section{Collection of Water Samples}

Once microbial consortia have been collected, it is critical to attempt to culture them in water with the same chemistry as found in the coal seam. Additionally, microbes could be isolated from the formation water and used in the coal-enrichments to determine if viable microbes found in the formation water could indeed bioconvert coal. Therefore, several wells were sampled to collect formation water and microbes (Tables 1 and 4). Figure 10 shows the water sample collection activities. The samples were collected directly from the wellhead into clean and pre-sterilized serum bottles (Figure 10c; see \#). To avoid microorganisms that could grow in the wellhead piping under aerobic 
conditions as much as possible, we followed the following procedure. We had obtained spare pipe-fittings bearing outlet valves that are seen Figs. 10b. These fitting were cleaned and sterilized at VT and transported to the field. Right before the collection of water sample from a well, the existing wellhead piping was flushed by letting some water out (Figure 10b) and then it was replaced with a sterilized unit. The well water was collected through this clean and sterile outlet (Figure 10c). Immediately after that, the bottles were sealed with a robber stopper and aluminum crimp (Balch and Wolfe 1976; Mukhopadhyay et al. 1999) and the contents of the bottles were made anaerobic via evacuation and placed under $\mathrm{N}_{2}+\mathrm{CO}_{2}$ atmosphere (80:20, vol/vol; $5 \mathrm{psi}$ ) following the

procedure described above (see Figure 6 and Figure 10d; , \#\# and \#\#\#). This step helped to maintain the integrity of the sample and minimized exposure to air (oxygen). An exposure to oxygen profoundly influenced the chemistry of the collected water, sometimes turning the color to black; compare \#\# with \#\#\# in Figure 10d. The coal and water samples were transported to the Mukhopadhayay laboratory within 2 days of collection via an express delivery service and these were used to set up enrichment cultures.

\section{COAL BIOCONVERSION STABLE MICROBIAL ENRICHMENT DEVELOPMENT}

This task was performed at the Virginia Bioinformatics Institute, Virginia Tech, under the direction of Dr. Biswarup Mukhopadhyay. The following materials were used to set up the enrichments:

- Whole coal core and cutting samples collected from CBM wells. These samples represented the source of substrates (degradable parts of coal), microorganisms and trace nutrients (such as metal ions).

- Fresh coal mine samples: Served as substrate source [Rationale: This material provides a clear source of substrates. Coal cuttings are the most contaminated substrate that we used. The whole cores are also contaminated with drilling mud. With mined coal we had a better focus on the coal constituents.

- Maceral Isolation: Represented one specific type of coal organic matter to be used as substrates for bioconversion. Different macerals may be more degradable microbiologically so the evaluation of various maceral fractions would allow us to key in on coal structures that may enhance biodegradation. The macerals were provided by Dr. John C. Crelling (Southern Illinois University), whose laboratory is one of the few in the world capable of isolating specific macerals from coal. 
- Maceral Isolation: Additionally, Dr. Crelling is an expert in the coal chemistry and provided guidance in using maceral fractions for setting up our enrichments. Due to the apparent bioavailability and potential biodegradability the resinite maceral was a key component for the enrichments. Resinite was derived from resinous material in land plants and is rich in hydrogen.
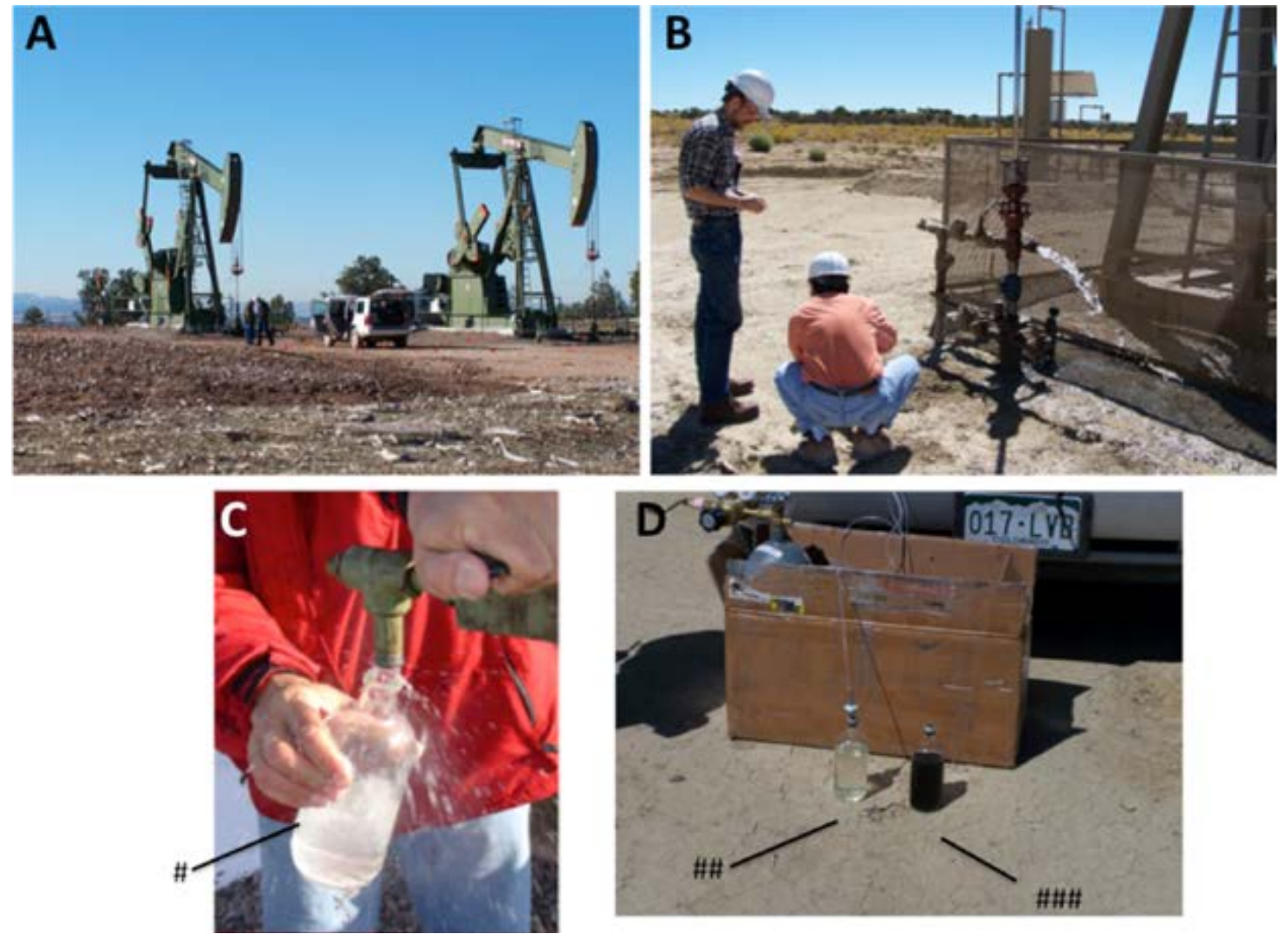

Figure 10. Collection of formation water from a CSG well. Redox measurements at the well head indicated that the water samples collected were still under anaeroibic conditions.

- Water from producing CBM wells: Formation water is a source of microorganisms and trace elements as well as major nutrients. Utilization of formation water from CBM wells water helps to provide realistic native habitat conditions for the microorganisms. One of the drawbacks is that the soluble reduced carbonaceous nutrients present in well water have the potential to inhibit or prevent the degradation of coal thereby reducing the chances of enriching coal-degrading microorganisms.] 
- Synthetic Media prepared in the laboratory. Such a medium could be advantageous because it may allow the development of enrichments that would degrade coal or coal-associated compounds. The primary drawback is that these synthetic media may lack critical nutrients that are essential for the growth of coal-bed microorganisms.

- Sediment and/or Environmental Samples that could be a source of microorganisms and trace nutrients The primary advantage of using such samples is that these materials expand the range of microorganisms to be examined for their potentials of contributing to the degradation of coal. Unfortunately, these samples might lack coaldegrading microorganisms and could potentially introduce unwanted substrates that prevent the degradation of coal and reduce the chances of enriching coal-degrading microorganisms.

Using the various coal and microbial samples described above enrichment mixtures were developed. The time and cost of experimenting with and developing such enrichment mixtures is significant which is why only a selected number of samples collected during the research (Tables 1 through 4) were utilized for the enrichment mixtures.

Enrichment Mixture 1: With coal and synthetic media prepared in the laboratory

The cutting samples or parts of whole core collected from the CBM well drilling sites and various synthetic media prepared in the laboratory were used in these experiments. To avoid exposure to oxygen, all steps involving open handling of coal core or cutting samples occurred inside an anaerobic chamber (Figure 11a). The coal core samples were crushed into small pellets or powdered inside an anaerobic chamber (Figure 11a) with a hammer and mortar and pestle. Often to avoid contaminating foreign materials on the surface, the internal contents of a coal core were collected by drilling (Figure 11b).

The smaller pieces of coal core, powdered coal core, or coal cuttings were then placed inside clean and sterile serum bottles (Figure 11b). The bottles were sealed with rubber stoppers and aluminum crimps, taken outside the anaerobic chamber, evacuated to remove sorbed methane, $\mathrm{CO}_{2}$ and other gases and the contents were placed under a desired gas atmosphere $\left(\mathrm{H}_{2}+\mathrm{CO}_{2}, 80: 20 \mathrm{vol} / \mathrm{vol}, 200 \mathrm{kPa} ; \mathrm{N}_{2}+\mathrm{CO}_{2}, 80: 20 \mathrm{vol} / \mathrm{vol}, 200\right.$ $\mathrm{kPa}$ (Figure 9c). Then a proprietary, low-salt medium that has been extensively used in work with the methane forming archaea (Balch and Wolfe 1976), and stock solutions of trace metals and vitamins (Balch and Wolfe 1976; Mukhopadhyay et al. 1999), and common salts such as sodium chloride $(\mathrm{NaCl})$ were added, as desired, to the bottles containing coal. The vitamin solution was sterilized via filtration and other stock solutions were autoclaved prior to their use. $\mathrm{NaCl}$ was added to match the salinity of the well water. Mixtures with and without vitamins were set up. The vitamins were added to address the possibility that some of the organisms participating in the degradation of coal 
could require or be stimulated by vitamins; such organisms are called vitamin auxotrophs. Use of such microorganisms in a future commercial-scale operation for the production of natural gas via degradation of coal will not pose a serious problem, because the need for expensive vitamins could be eliminated by cloning the respective biosynthesis genes into the auxotrophic strains. All mixtures were then incubated at room temperature $\left(25{ }^{\circ} \mathrm{C}\right), 40{ }^{\circ} \mathrm{C}$ and $50{ }^{\circ} \mathrm{C}$, and these designs were based on bottom hole temperature data for San Juan Basin well water

Enrichment Mixture 2: With coal and CBM well water

The details presented above for Mixture 1 are also applicable here with the exception that collected formation water collected from CBM wells replaced all liquid additions. The CBM formation water was transferred from the anaerobic collection bottle taken at the well site to the enrichment mixtures by use of sterile and anaerobic syringes fitted with sterile needles following established protocols that have been used previously by Mukhopadhyay and colleagues for their research with strict anaerobes (Balch and Wolfe 1976; Mukhopadhyay et al. 1999).

Enrichment Mixture 3: With mined coal and CBM well water

The details presented above for Mixture 2 apply here, except fresh coal samples collected from active coal mines replaced coal cuttings or whole core. Water samples collected form CBM wells were used for all liquid additions.

Enrichment mixture 4: With macerals and CBM well water

The Mixture composition was same as that described above for Mixture 3 above, except coal was replaced with individual coal macerals in an attempt to identify which macerals had the best chance of biodegradation.

Enrichment Mixtures 5,6 and 7: With microbial inocula derived from other non-coal sources

Same as mixture 1-4, except each was supplemented with a non-coal-bed inoculum, such as sediment from a fresh water pond, samples from La Brea Tar Pits (near Los Angeles, CA), and sediments from Chesapeake Bay Black Marsh in Virginia (Tables 2 through 4) 

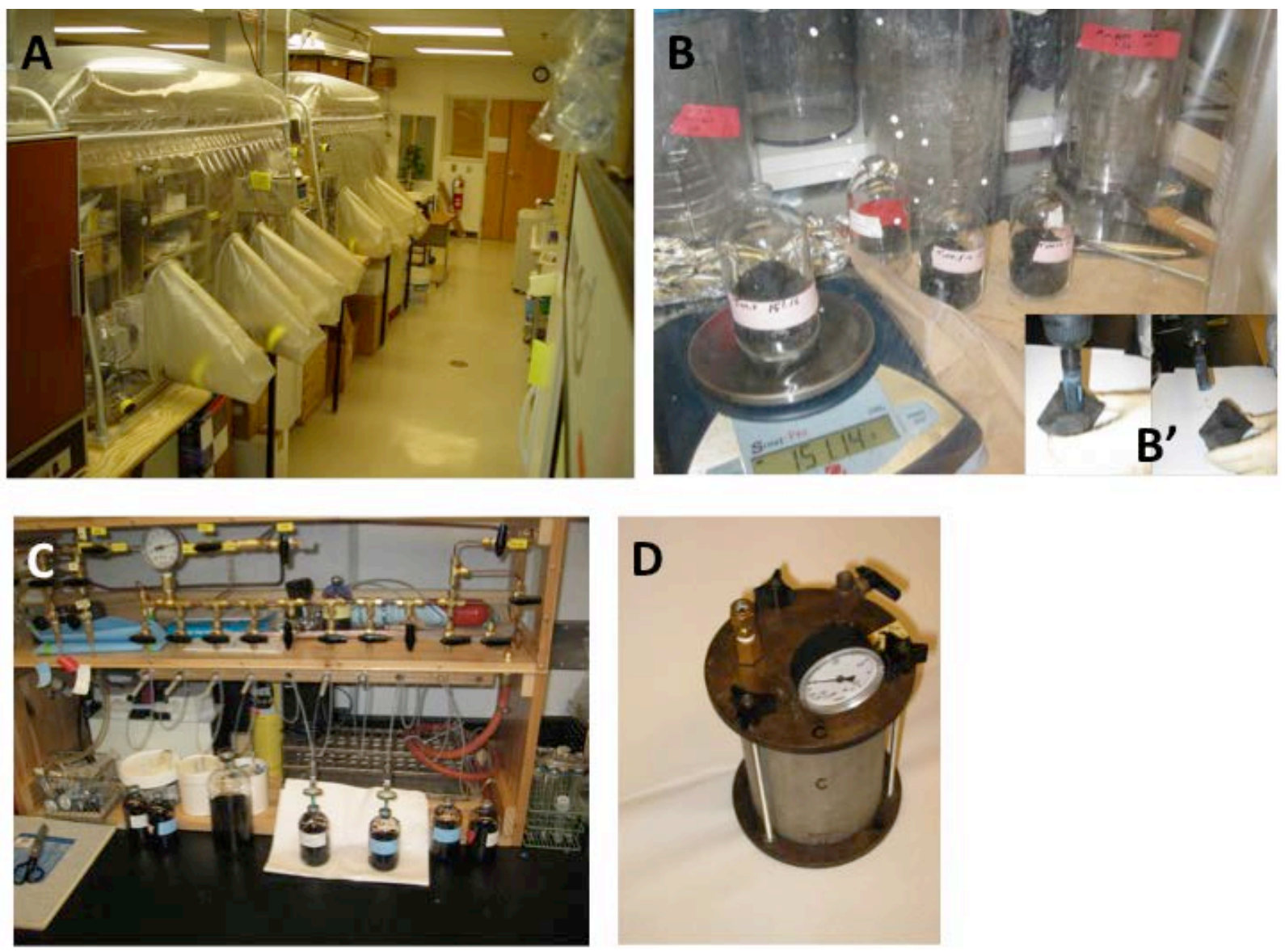

Figure 11. Laboratory processing of coal samples collected from CBM wells and outcrops

Enrichment Mixture 8: represents a combination of all mixtures and processes. Coal collected from coal mines, the synthetic medium described in Mixture 1 and inoculum from an advanced stage of one of the above enrichment cultures was tested. This system was used to determine whether the consortia developed in enrichment Mixtures 1 through 7 could generate methane from coal in sustained manner. 


\section{Evaluation of Enrichment for Methane Formation Potential}

Evaluation of the enrichment cultures was also performed at the Virginia Bioinformatics Institute and followed the scheme shown in Figure 12. The incubation mixtures as described in the enrichment cultures above were examined for methane production. For this purpose, a sample of the head space of each culture bottle was assayed for methane by us of gas chromatograph (Shimadzu Corporation, Model GC 2010) fitted with a flame ionization detector and a $0.53 \mathrm{~mm} \times 30 \mathrm{~m}$ Supelco Carboxen ${ }^{\circledR}$ 1010 PLOT column (Sigma-Aldrich Co.). The column, detector, and injector were maintained at 100,150 , and $150{ }^{\circ} \mathrm{C}$, respectively. The carrier gas $\left(\mathrm{N}_{2}\right)$ flow rate was 1 $\mathrm{ml} / \mathrm{min}$. A methane standard (Matheson Tri-Gas, Montgomeryville, PA) was used for calibration of the equipment. Whenever a primary culture mixture generated methane, it was used as inoculum for starting a second stage culture (coal + inoculum + desired gas atmosphere + desired nutritional supplements). If the second stage culture showed methane formation from coal, then the transfers were repeated multiple times with the goal of obtaining a stable mixed culture that consistently produced methane from coal.

\section{Evaluation of Enrichment cultures}

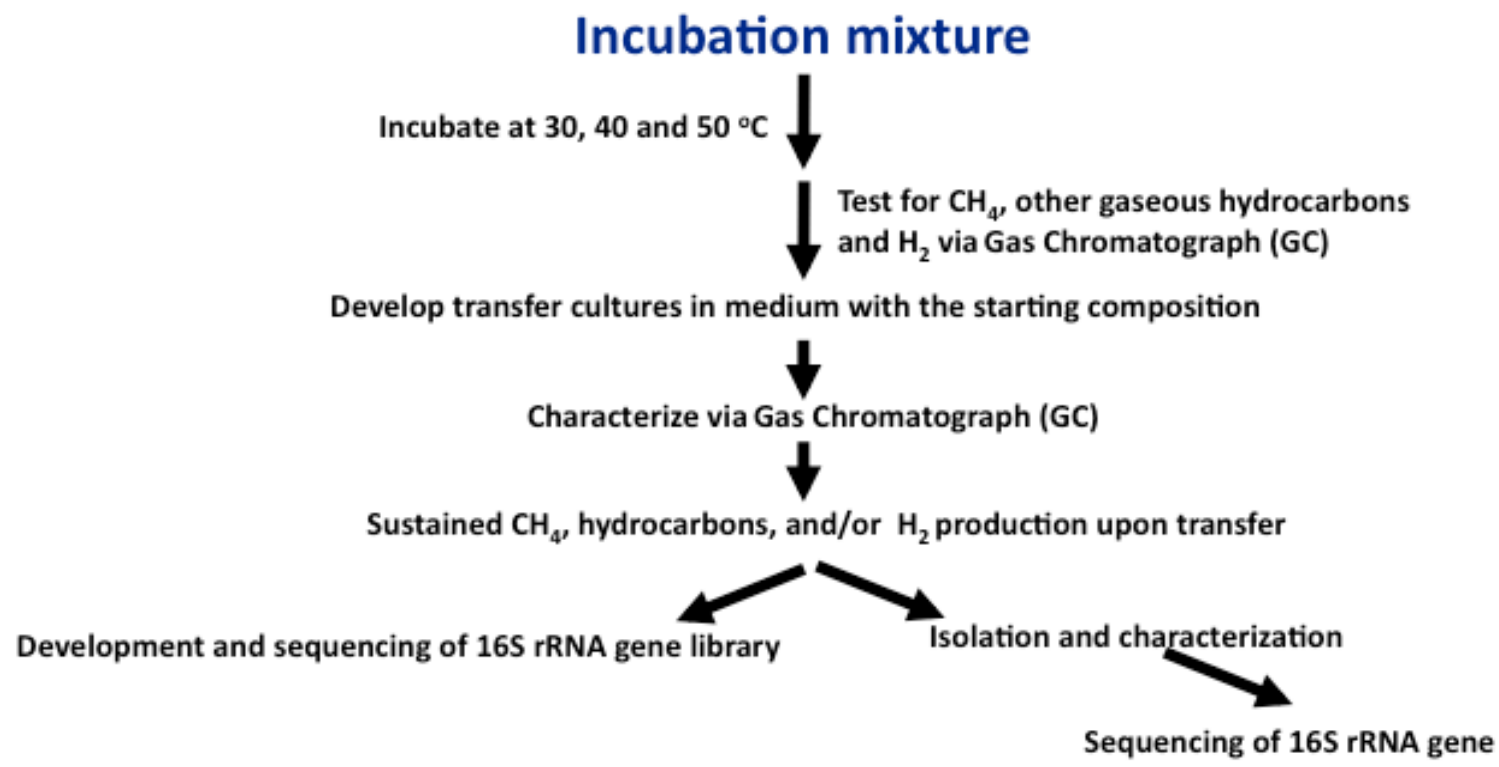

Figure 12. Evaluation protocol for enrichments 
Nearly all of the cultures produced methane, but even after . However, even after more than 2.5 of intense effort we could not obtain or develop an enrichment from various variations of Mixtures 1 through7 that would provide sustained methane production from coal mine samples in the formulation described in enrichment Mixture 8. Attempts that included the addition of formation water from CBM wells as stimulant also failed to achieve sustained methane production, and in such cases, the small amount of methane that was generated was due to readily utilizable substrates such as small organic molecules that were present in the coal formation water.

The VT Principal Investigator concluded that the sporadic reports of methane production from coal were most likely due to the presence of contamination of the coal by readily utilizable substrates in the cultures. One very obvious example is the drilling liquid that contains easily utilizable substrates for anaerobic microorganisms (see Figure $5 \mathrm{f}$ of core covered drilling fluid and mud). It is known that starch and wood dusts/chips (cellulosic materials) are used as lubricants in the drilling operations and these are readily converted to methane in anaerobic niches of nature (Zinder, 1993). Most of our enrichments contained hydrogenotrophic methanogens so that the addition of hydrogen and carbon dioxide to these cultures provided vigorous methane production and this could be sustained in transfer cultures with supplies of hydrogen and carbon dioxide. Electron microscopic observations showed that the enrichment cultures 1through 7 contained microorganisms of various morphotypes and they remained viable as they continue to persist upon sequential transfers. The exception was enrichment Mixture 1, which produced unstable enrichments and this observation once again suggested that coal was not degraded significantly in the one to two year time span. The inability to find enrichment cultures capable of bioconverting coal in a sustainable manner prevented the evaluation and impact on maceral composition on bioconverions rates and the characterization of possible bioconversion pathways. Without being able to isolate and characterize the participating microbes within the consortia, we could not determine an optimum mixture of microbes for the biodegradation of coal. 


\section{ECONOMIC EVALUATION OF THE IN SITU BIOCONVESION PROCESS}

Although our laboratory results did not conclusively or inconclusively demonstrate that the in situ bioconversion was feasible, an economic evaluation of the in situ bioconversion process was undertaken. We believe that the technology can be developed, but it will take considerable more time and monies than allocated to this SBIR project. The following economic evaluate assumes that subsurface coal bioconversion is indeed possible and then through various assumptions determines. Additionally, we examined market conditions that were active during the research project from approximately 2003 through 2006. The emergence of shale gas technology over the past few years has significantly increased US natural gas proved reserves. This has resulted in much lower Henry Hub natural gas prices than predicted in this economic evaluation, and current natural gas prices probably would not justify additional research into the coal bioconversion technology in the near future. Our economic evaluation suggests that injecting nutrients into coal reservoirs will be more cost effective that growing and transporting microbes to the well site. Once the technology has been developed to the point of commercialization and then assuming market conditions support scaling up the technology, the in situ cost of bioconversion could be less than $\$ 1.50$ per Mcf and possibly as low as $\$ 0.25$ per Mcf with higher bioconversion rates and a more efficient means of activating and maintaining the subsurface bioconversion process.

\section{Overview}

The bioconversion technology is part of the natural gas supply chain that includes all of the production and distribution steps from exploration to delivery to the final enduses such as homes and businesses (Figure 13). The bioconversion process lies between the exploration and extraction stages of natural gas from coal beds or other organic-rich sediments. The process is applied to coal beds whose physical location is already well established, thereby reducing the expense of locating new gas reserves. The extraction of the biologically-generated natural gas from coal beds occurs after the coal and/or sequestered carbon dioxide have been converted into methane.

The next logical step in the exploration and production of natural gas from coal seams, and a technology that will address the increased demand for natural gas over the next SEVERAL decades, will be Microbially Enhanced Coalbed Methane (MECoM). MECoM imitates and enhances the natural process of secondary biologic generation of gas ("biogenic" gas) in coal beds that occurs in coal basins worldwide. The process is similar to microbially enhanced oil recovery (MEOR) that has been applied to oil reservoirs for decades. MECoM involves the introduction of different types of microbes (microbial consortia) and/or nutrients into coalbed methane wells to stimulate coalbed methane production through the generation of biogenic gases (Figure 14). 


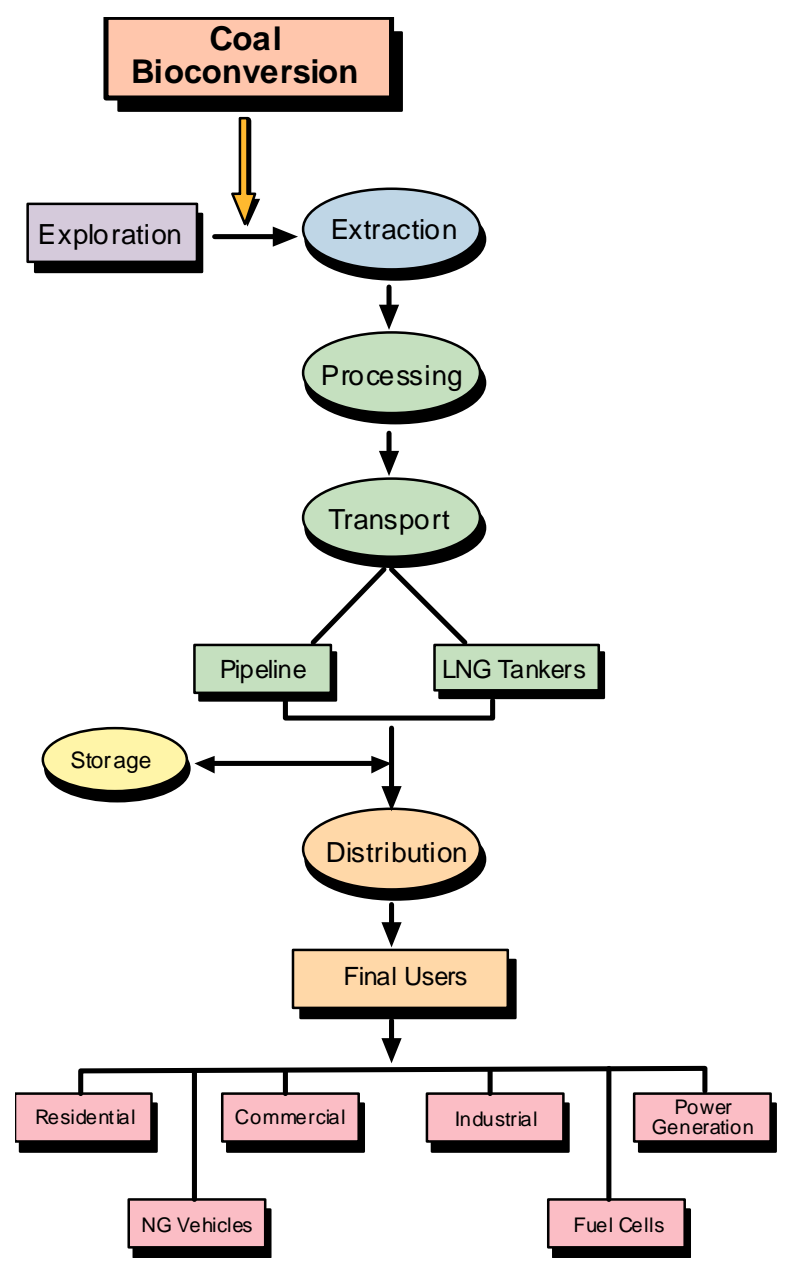

Figure 13. Natural gas supply chain (Info Comm, 2005)

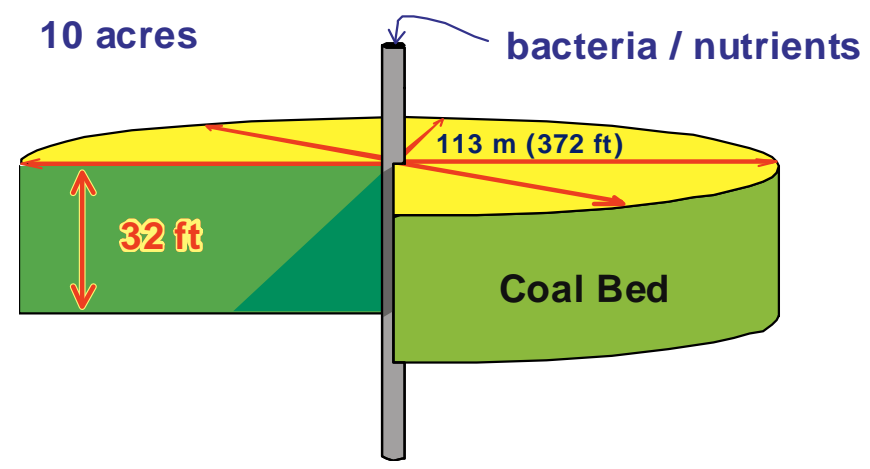

Production rate: $296 \mathrm{Mcfd}$

Annual production: $108 \mathrm{MMcf}$ Income: \$540,200 (\$5 per Mcf)

Figure 14. Microbially Enhanced Coalbed Methane (After Scott 1999). 
The in situ bioconversion of one-hundredth of one percent (0.0001) of the coal resources in the United States would potentially result in the generation of 23 trillion cubic feet (Tcf) of natural gas, or 4 billion barrels of oil equivalent (BOE). Therefore, the in situ bioconversion of a small fraction of the coal in the U.S. represents a large supply of natural gas based on current consumption rates and approximately a \$115 billion dollar industry, assuming gas prices conservatively at only $\$ 5.00$ per thousand cubic feet (Mcf). Unfortunately, natural gas prices have declined from \$13.82 per Mcf (EIA, Natural Gas Weekly Update) in October, 2005 to less than \$3.00 per Mcf in 2012. The secondary industries and technologies that would undoubtedly spin off from the bioconversion industry are difficult to quantify at this point in time, but they would have a significant impact on the economy of the United States and worldwide. This emerging technology has the potential to significantly impact domestic and international energy sectors and may pave the way for the upcoming hydrogen economy.

\section{$\underline{\text { Value Proposition }}$}

The value proposition for coalbed methane operators, conventional oil and gas operators, and coal-fired power plants looking for environmentally-friendly natural gas supplies is to provide them with the technology to generate natural gas from coal beds using enhanced microbial technologies that lower exploration and development costs.

Most of the expenses in oil and gas production are associated with infrastructure related to field development. For example, in 2004, ExxonMobil spent $86 \%$ of replacements costs ( $\$ 9.1$ billion of $\$ 10.5$ billion total) on field development. Application of the bioconversion process at abandonment of primary coalbed methane production will allow operators to extend the life of the field with production infrastructure that is already in place, thereby lowering total operating expenses.

Exploration and development costs from 1999 to 2003 ranged from \$0.25 per thousand cubic feet equivalent (Mcfe) to \$2.58 Mcfe, averaging \$1.23 Mcfe. Over the past few years, companies have paid anywhere from \$1.33 to \$2.25 Mcfe by purchasing gas reserves. We believe that the life of coalbed methane fields can be extended for years or decades at costs less than $\$ 1.00$ per Mcf, possibly as low as $\$ 0.25$ Mcf, once the correct combination of microbes and nutrients is determined. Therefore, the technology will be a cost-effective way of generating natural gas in situ while simultaneously lowering carbon dioxide emissions to the atmosphere. These price estimates do not take into consideration income received from carbon tax credits derived from sequestrating carbon dioxide.

The coal bioconversion business model would commercialize the process and products for microbially enhanced coalbed methane (MECoM) production in which microbes and/or nutrients are injected into coal beds where they will convert sequestered carbon dioxide and coal into methane. The groups of microbes (microbial consortia) and 
their nutritional requirements are carefully selected based on a detailed understanding of coal chemistry and existing microbial populations to maximize methane generation rates in the coal beds. MECoM can be applied to most coal beds regardless of coal quality, coal rank, sulfur content, and ash content.

The company, would make available bioconversion services to the oil and gas industry by providing the technology and expertise to bioconvert coal and sequestered carbon dioxide into natural gas (methane). Patented microbial consortia will be provided by the company under time-restrictive licenses to larger companies that wish to utilize the bioconversion process. The company would also provide the microbial consortia and expertise to smaller operators who do not wish to be directly involved with implementing the bioconversion process in return for a one-time charge for applying the technology and a proposed five percent overriding royalty interest (i.e. five percent of the gross production) on incremental gas production for the wells. It is important to note that operators have indicated that a higher overriding royalty interest can be negotiated if the bioconversion technology is applied to abandoned coalbed methane fields.

The commercialization strategy would be for the company to take advantage of a rapidly expanding market derived from a new technology that provides investment opportunities. Early commercialization activities should focus on field test demonstrations of the technology at several possible locations. Coalbed methane operators would provide the necessary equipment and expertise to re-enter wells, inject microbes and nutrients, and provide the means by which the technology is assessed. The microbes for the field tests could intially be grown in a fermentation reactor at Virginia Tech or other biological facility. An agreement would be made with the coalbed methane operators that if the bioconversion technology is successful, the company will retain part of the coal gas production as an overriding royalty interest. This income would provide additional internal funds for the next commercialization steps.

Upon successful completion of the field tests, funding derived from equity investors will be used to grow more microbes in fermentation reactors at Virginia Tech or a company specializing in microbial growth. Alternatively, the companies directly involved with the field tests may want to invest in the company. The company would continue to seek alliances with other companies involved in similar bioconversion processes and consider sharing or purchasing IP from these organizations to strengthen its market position. Decisions regarding the application of the bioconversion technology within potential customer data base would initially be made at upper level management positions, but Regional Exploration Managers for large oil and gas operators are considered to be the customer since they will make the purchasing decisions. Most oil and gas operators are conservative, but they fully realize the inherent risks involved in exploration and will be open in attempting new technology. However, operators tend to follow the lead of their competitors who have been successful in their exploration and development efforts, so we anticipate an exponential growth in the industry over the first 
five to ten years. The following assumptions pertaining to purchasing power and the need for bioconversion technology are made:

Assumption 1: Top tier oil and gas operators and coal mining operations have sufficient capital to invest in the technology.

Assumption 2: Many coalbed methane fields will reach the abandonment stage over the next few years and operators are looking for ways to extend the life of their fields, including the injection of carbon dioxide into coals to enhance production. Additional exploration is possible on acreage held by the production of oil or gas, because operators want to extend field life as long as possible.

Assumption 3: In situ bioconversion of sequestered carbon dioxide that costs around $\$ 0.60 \mathrm{Mcf}$ for natural gas worth $\$ 5.00 \mathrm{Mcf}$ or more is an acceptable ROI for the operators, particularly if they receive carbon tax credits on the front end during $\mathrm{CO}_{2}$ injection. Unfor

Assumption 4: Oil and gas operators and coal mining operations are continuously seeking economically viable technology to increase gas reserves and/or to find cleaner burning fuels for electric power generation at a lower cost.

Assumption 5: As the technological success increases, the number of customers will increase at an almost exponential rate because of the highly competitive nature of oil and gas exploration. At some point, second tier operators may become viable customers.

Assumption 6: There will be a reasonable price for natural gas in the market place and the anticipated increase in natural gas demand over the next 15 to 20 years indicates that these customers have a very real need to replace and expand natural gas supplies.

\section{$\underline{\text { Market Size }}$}

The size of the in situ bioconversion market has not been defined previously. However, there are several approaches for determining the projected market size based on information gathered from various publications, primarily from Energy Information Administration reports (EIA, 2003, U.S. Crude Oil and Natural Gas, and Natural Gas Liquid Reserves, 2003 Annual Report, December 2004).

Total natural gas production in the United States in 2003 was 19.425 Tcf and the average wellhead price was \$4.98 Mcf, yielding an industry with annual sales of approximately $\$ 96.7$ billion; therefore, this value represents the total natural gas industry in the United States. Coalbed methane production in the U.S. totaled 1.6 Tcf or approximately $8 \%$ of the total domestic dry gas production. Assuming the same average 
wellhead price of $\$ 4.98 \mathrm{Mcf}$, then the coalbed methane industry had annual sales of nearly $\$ 8.0$ billion.

The Powder River and San Juan Basins currently have 39,000 and 5,250 coalbed methane wells, respectively (Bureau of Land Management, 2003; Meek and Levine, 2005). An additional 12,000 wells are expected to be drilled in the Powder River Basin, bringing the total number of wells in that basin to over 51,000 by 2013 (Billings Gazette, 2003; Bureau of Land Management, 2003). Continued infill drilling in the San Juan Basin may bring the total number of wells to 7,500 over the next few years. There are at least 10,000 additional existing coalbed methane wells in the rest of the country, bringing the total number of coalbed methane wells from all the coal basins in the United to an estimated 54,000 as of December 2004, with an average production rate of 81 thousand cubic feet per day (Mcfd). The total number of coalbed methane wells in 2015 may exceed 75,000 with an additional 10,000 wells in Canada. Additionally, the number of conventional oil and gas wells that penetrate coal beds but do not produce gas from the coal beds is in the millions.

To put the potential market size in perspective, we can estimate the revenue stream from only 13,750 coalbed methane wells (25 percent of current wells) generating an additional 50 Mcfd (extrapolated laboratory data suggest 296 Mcfd) from the coal bioconversion process. Based on these assumptions, the total incremental gas production from the bioconversion process would be 251 Bcf per year, worth an estimated $\$ 1.25$ billion dollars per year at $\$ 5.00$ per Mcf. If the technology were applied to all of the existing wells, then the annual market size would be over 1 Tcf per year, valued at $\$ 5$ billion per year.

The total gas market for the bioconversion technology can be defined in part by the total gas industry worldwide, but can be segmented into smaller markets based upon specific market niches targeted for early development of the bioconversion technology. Total U.S. gas production in 2003 can be subdivided into unconventional production, particularly coalbed methane, to better define the market potential. World gas production in 2003 was 92.5 Tcf, whereas total U.S. gas production (wet and dry) totaled 20.2 Tcf or 22 percent of worldwide production. Most of the U.S. gas production came from intermediate and large oil and gas operators who make up only a small fraction of the total number of operators (Figure 15). 


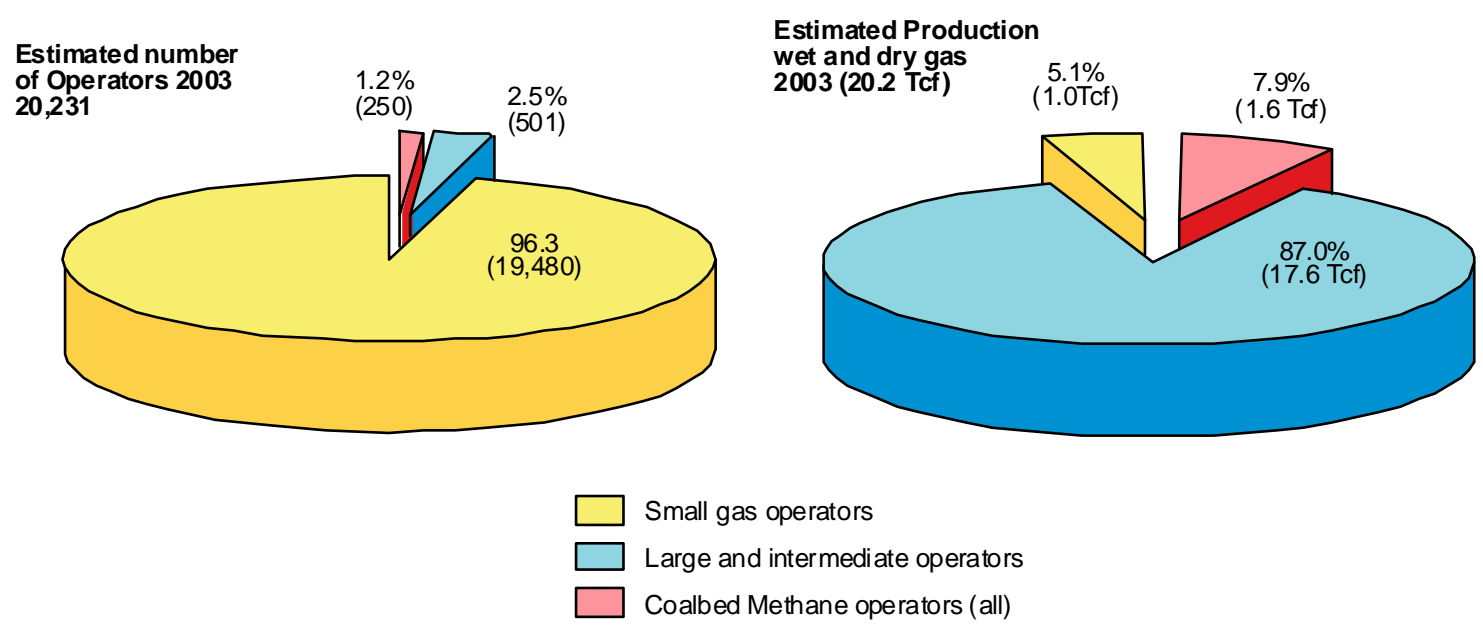

Figure 15. Total U.S. gas production by operator size and type (data from EIA, 2004)

There is a minimum of 250 coalbed methane operators, of which 50 percent are believed to be in the intermediate to large category. Nearly all of the large and intermediate operators will participate, and smaller coalbed methane operators may also participate since their overhead costs are much lower, indicating that they require a smaller ROI in exploration and development operations. Additionally, it should be noted that many large and intermediate non-coalbed methane operators control producing properties where coal seams are present. The bioconversion technology will open up at least some of these untapped coalbed methane resources for development. Therefore the 250 total potential customer prediction may be much higher.

\section{$\underline{\text { Pricing Strategies and Market Penetration }}$}

The bioconversion pricing strategy is heavily influenced by whether the objectives are to generate cash or penetrate the market. For immediate cash generation, the price would have to be relatively higher, but this requires minimal competition, whereas significant market penetration ordinarily requires a lower product price in a highly competitive market. We are creating a new bioconversion technology market that currently does not exist, indicating that initial competition is low. Therefore, our initial price can remain relatively high, but will be adjusted over time depending on market growth and structure. We believe the greatest income potential is in the form of overriding royalty interest (ORRI) where the company benefits when the technology is successfully applied. Therefore, the company should charge a reasonable price for applying the technology initially, but expect the greatest returns on our investments to occur during the years following application of the bioconversion process.

Market penetration can be determined from various models including a bottom up approach and a top-down approach. We believe that the bottom up approach based on the number of units that will be sold to the target market provides the best indicator of market penetration and potential growth, because the company can easily assume prices 
for their product and estimate the income received from producing coalbed methane wells. The top-down approach is problematic since the company would receive income initially from the number of products sold and annual service fees, but the majority of the income generated from the product occurs in subsequent years after the product has been "sold", in the form of an over-riding royalty interest (ORRI). In any given year, approximately one-third of the income may come from new well applications and existing well services, whereas two-thirds of the revenue could come from gas production. 


\section{REFERENCES}

Apolinario, E.A. and K.R. Sowers. 1996. Plate colonization of Methanococcus maripaludis and Methanosarcina thermophila in a modified canning jar. FEMS Microbiol Lett. 145: 131-137.

Balch, W. E., and R. S. Wolfe. 1976. New approach to the cultivation of methanogenic bacteria: 2-mercaptoethanesulfonic acid (HS-CoM)-dependent growth of Methanobacterium ruminantium. Appl. Environ. Microbiol. 32:781-791

Boone, D. R., W. B. Whitman, and P. Rouvière. 1993. Diversity and taxonomy of methanogens, p. 35-80. In J. G. Ferry (ed.), Methanogenesis: ecology, physiology, biochemistry, and genetics. Chapman \& Hall, New York, N.Y.

Burlage, R.S., 1998, Techniques in Microbial Ecology, Chapter 33, The Methanogenic Bacteria in The Procaryotes, Oxford Press, page 113-136.

Byrer, C. W., and Guthrie, H. D., 1999a, Appalachian coals: Potential reservoirs for sequestering carbon dioxide emissions from power plants while enhancing coalbed methane production: Proceedings International Coalbed Methane Symposium, The University of Alabama, Tuscaloosa Alabama, p. 319-328.

Byrer, C. W., and Guthrie, H. D., 1999b, Carbon dioxide sequestration potential in coal deposits (abs) American Association of Petroleum Geologists Annual Conventions, Program with Abstracts, p. A18.

DOE/EIA, 1996, U.S. Coal Reserves: A review and update. DOE/EIA 0529(95), pp. 1-7. Energy Information Administration, 2002, U.S. crude oil, natural gas, and natural gas

liquids reserves, 2001 Annual Report; DOE/EIA-0216(2001)

Juretschko, S., G. Timmermann, M. Schmid, K.H. Schleifer, A. Pommerening-Roser, H.P. Koops, and M. Wagner.1998. Combined molecular and conventional analyses of nitrifying bacterium diversity in activated sludge: Nitrosococcus mobilis and Nitrospira-like bacteria as dominant populations. Appl. Environ. Microbiol. 64:3042-3051.

Herzog, H. J., 1998, Understanding sequestration as a means of carbon management; Appendix D, Proceedings of the Stakeholders' Workshop on Carbon Sequestration, Massachusetts Institute of Technology, June 22-23, 1998. MIT EL 98-002, variously paginated.

Leadbetter, J.R., and J.A. Breznak, J.A. 1996. Physiological ecology of Methanobrevibacter cuticularis sp. nov. and Methanobrevibacter curvatus sp. nov., isolated 
Leahy, Patrick, 2001, Statement of Senator Patrick Leahy at the Introduction of the "Clean Power Plant and Modernization Act of 2001" June 28, 2001.

Mukhopadhyay, B., E. F. Johnson, and R. S. Wolfe. 1999. Reactor-scale cultivation of the hyperthermophilic methanarchaeon Methanococcus jannaschii to high cell densities. Appl. Environ. Microbiol. 65:5059-5065

Pernthaler,A., J. Pernthaler, and R. Amann. 2002. Fluorescence in situ hybridization and catalyzed reporter deposition for the identification of marine bacteria. Appl Environ Microbiol. 68:3094-3101.

Scott, A. R., 2001, Hydrogeologic Controls on Carbon Dioxide Sequestration in Coal Beds; American Association of Petroleum Geologists Annual Conventions, Program with Abstracts, p. A18

Scott, A. R., Kaiser, W. R., and Ayers, W. B., Jr., 1991, Composition, distribution, and origin of Fruitland Formation and Pictured Cliffs Sandstone gases, San Juan Basin, Colorado and New Mexico, in Schwochow, S. D., Murray, D. K., and Fahy, M. F., eds., Coalbed methane of western North America: Guidebook for Rocky Mountain Association of Geologists fall conference and field trip: Rocky Mt. Assoc. of Geologists, p. 93-108.

Scott, A. R., Kaiser, W. R., and Ayers, W. B., Jr., 1994, Thermogenic and secondary biogenic gases, San Juan Basin, Colorado and New Mexico-implications for coalbed gas producibility: American Association of Petroleum Geologists Bulletin, v. 78, no. 8, p. 1186-1209

Zinder, S. H. (1993) in Methanogenesis: Ecology, Physiology, Biochemistry, and Genetics, ed. Ferry, J. G. (Chapman \& Hall, New York), pp. 128-206. 